NBER WORKING PAPER SERIES

RURAL DEMOGRAPHY, PUBLIC SERVICES AND LAND RIGHTS IN AFRICA:
A VILLAGE-LEVEL ANALYSIS IN BURKINA FASO

\author{
Margaret S. McMillan \\ William A. Masters \\ Harounan Kazianga \\ Working Paper 17718 \\ http://www.nber.org/papers/w17718
}

\author{
NATIONAL BUREAU OF ECONOMIC RESEARCH \\ 1050 Massachusetts Avenue \\ Cambridge, MA 02138 \\ December 2011
}

\begin{abstract}
We are grateful to the NBER African Successes Project for financial support, and thank Moussa Kabore and colleagues in the Direction de la Prospective et des Statistiques Agricoles et Alimentaires (DPSAA) of Burkina Faso for survey implementation, Jose Castillo for research assistance, and Jun Folledo of IFPRI for GIS calculations. The paper was much improved by valuable suggestions from Will Dow and other participants at the Zanzibar Conference of the NBER African Successes Project, August 3-5, 2011, as well as comments from Rohini Pande and Remi Jedwab. The views expressed herein are those of the author and do not necessarily reflect the views of the National Bureau of Economic Research.
\end{abstract}

NBER working papers are circulated for discussion and comment purposes. They have not been peerreviewed or been subject to the review by the NBER Board of Directors that accompanies official NBER publications.

(C) 2011 by Margaret S. McMillan, William A. Masters, and Harounan Kazianga. All rights reserved. Short sections of text, not to exceed two paragraphs, may be quoted without explicit permission provided that full credit, including $(\odot)$ notice, is given to the source. 
Rural Demography, Public Services and Land Rights in Africa: Å Village-Level Analysis in Burkina Faso

Margaret S. McMillan, William A. Masters, and Harounan Kazianga

NBER Working Paper No. 17718

December 2011

JEL No. F20,H41,I18,J11,O12,O20

\begin{abstract}
$\underline{\text { ABSTRACT }}$
This paper uses historical census data from Burkina Faso to characterize local demographic pressures associated with internal migration into river valleys after Onchocerciasis eradication, combined with a new survey of village elders to document change over time and differences across villages in local public goods provision, market institutions and land use rights. We hypothesize that higher local population densities are associated with more public goods and a transition from open-access to regulated land use. Controlling for province or village fixed effects, we find that villages' variance in population associated with proximity to rivers is closely correlated with higher levels of infrastructure, markets and individual land rights, as opposed to familial or communal rights. Responding to population growth with both improved public services and private property rights is consistent with both scale effects in public good provision, and changes in the scarcity of land.
\end{abstract}

Margaret S. McMillan

Tufts University

Department of Economics

114a Braker Hall

Medford, MA 02155

and International Food Policy Research Institute

and also NBER

margaret.mcmillan@tufts.edu

William A. Masters

Tufts University

william.masters@tufts.edu
Harounan Kazianga

Oklahoma State University

harounan.kazianga@okstate.edu 


\section{Rural Demography, Public Services and Land Rights in Africa: A Village-Level Analysis in Burkina Faso}

\section{Introduction and Motivation}

An unusual factor in Africa's $20^{\text {th }}$-century agricultural development was a relatively low initial level of average population density coupled with unusually high rates of rural population growth over the last 30 years. As shown in Figure 1, Africa's year-to-year rate of rural population growth rose above that of Asia around 1975, peaked in 1990, and only recently has fallen below the highest levels ever seen in other regions. All regions have seen a rise and then fall in their annual rates of rural population growth, but in the post-1975 period Africa's growth rate rose more recently and reached a higher level for a longer time than that of other regions.

This paper investigates the link between rural population and the local institutions and infrastructure needed for market development in agriculture. We use spatial differences in settlement patterns and migration exposure to test how rural public goods and land-use rights have responded to demographic change. Our central hypothesis is that recent increases in rural population densities are associated with a wider spread of rural infrastructure, public services and local marketplaces; and a transition from open-access to regulated land use, including stronger individual property rights and more reliance on the rule of law to adjudicate disputes.

Our data come from Burkina Faso, a landlocked West African country of about 13 million people. As shown in Figure 1, from 1950 to 2005 Burkina Faso's rural population growth rate rose even more dramatically than that of Africa as a whole, to a peak above $2.5 \%$ per year. Burkina's rural population growth rate is projected to decline rapidly in the coming decades, but will remain well above zero until the absolute size of the urban population becomes large enough for the annual growth of towns and cities to absorb each year's increase in the country's entire population. Figure 1 shows that rapid growth in Burkina Faso's rural population was not uniform in time, with a temporary reversal in the 1980s that may have been associated with migration to Cote d'Ivoire or other factors, followed by a burst of catch-up growth and downward projections until urbanization is sufficient to achieve zero rural population growth around 2050 . 
Historically, Burkina Faso has had large movements of rural people to its own cities and a large migration to coastal Cote d'Ivoire after colonization. A large number of those migrants later returned, including many who were forcibly repatriated following civil unrest in Cote d'Ivoire starting in the late 1990s. In addition, the donor-funded Onchocerciasis Control Program quickly eradicated river blindness starting in the 1970s, leading to large population movements into river valleys. These demographic shocks affected villages across Burkina Faso in different ways depending on their location, creating unusual variance in subsequent rural population density with which to study the impact of rural demography on local institutions and infrastructural investments.

We hypothesize that changes in rural population growth change the payoffs from collective action, making it relatively more urgent to develop market infrastructure and institutions. This hypothesis follows Boserup (1965), who argued that rising rural population densities create incentives not only for farm-level adoption of more input-intensive techniques and "induced invention" of new technologies in response to factor scarcity as suggested by Hicks (1932), but also induced institutional changes to allocate newly-scarce natural resources more efficiently. A link between rural population density and rural public goods could also be due to political pressures or indivisibilities and scale effects in the provision of infrastructure and institutions. Both relative-price and scale effects could be subject to time lags, leading rural population growth to have a Malthusian effect in the short run, even as it facilitates the institutional and technological innovations needed for later agricultural productivity growth.

Modern analyses of how population density and factor scarcity affect agricultural development were pioneered by Hayami and Ruttan (1971) for the U.S. and Japan, and tested in a large subsequent literature such as Olmstead and Rhode (1993). Only a few of these papers (e.g. Lin 1995) focus on the emergence and adoption of institutions; most ask how institutions affect technology adoption, such as Kazianga and Masters (2002, 2006). Focusing on rural demography also expands on our other previous work regarding the role of environmental factors in economic growth (Masters and McMillan 2001) and African policy choices (McMillan 2001, McMillan and Masters 2003). Here, we use within-country variation in village size and access to public services, infrastructure and property rights, to test how the public sector has responded to rural demographic change. 
Our focus on the specific challenge of rural population growth for agricultural development follows Johnston and Kilby (1975) among others. Most of the development economics literature concerned with demography has focused either on demographic transition in the population as a whole (including the demographic "drag" or "dividend" from age structure emphasized by Bloom and Williamson, 1998), or the structural transformation from farm to nonfarm employment in terms of output and employment shares (including the "growth bonus" associated with shifting from a low productivity to a high productivity sector as in Temple, 2005). Focusing on demographic conditions within rural areas addresses a distinctive aspect of Africa's post-independence economic decline, and grounds for optimism about the future as rural infrastructure and institutions adapt to higher levels of population density and the speed of further demographic change slows down.

The motivation for our approach begins with an economic view of rural demography. Simple accounting ensures that each locality's rural population growth is its natural increase (births minus deaths, which in turn are determined by age structure as well as age-specific mortality and fertility), plus or minus each year's net migration to urban or other rural areas. From an economic point of view, however, both fertility and migration are choice variables, and mortality may also be influenced by investment in health. Given this endogeneity, identification of a potentially causal effect of demography requires an exogenous shock to rural population size that occurs with sufficient speed and magnitude to induce a measurable societal response.

Our study design takes advantage of Burkina Faso's unusual demographic history, which includes two large waves of exogenous migration into specific rural areas from the 1970s. One wave flowed southwest out of the Central Plateau towards rivers in the Volta Valley, where it converged with another wave returning from Cote d'Ivoire. We use three rounds of census data in 1985, 1996 and 2006 to capture the resulting variation in village population, and compare that to variance in institutions and infrastructure as recalled by focus group interviews of village elders.

Our work contributes to an important gap in the literature on institutions and economic development identified by Pande and Udry (2006) who argue that "the research agenda identified by the institutions and growth literature is best furthered by the analysis of much more microdata than has typically been the norm in this literature." Specifically, we study both spatial and 
temporal variation in rural public services and property rights, focusing on diversity across villages in a setting with wide variation in exposure to clearly exogenous demographic shocks. The closest antecedent is probably Grimm and Klasen (2008), who test for endogenous adoption of land titles at the village level on Sulawesi in Indonesia. Our surveys include land rights and also consider a very wide range of other institutions, public services, and infrastructure used for market exchange. Methodologically, our use of focus groups to obtain village-level recall data on the location and availability of public services and land rights follows Chattopadhyay and Duflo (2004), building on a long tradition of participatory surveys in rural areas (e.g. Chambers 1994). This approach allows us to ask about many different types of public services as seen from the villagers' point of view.

This paper aims only to demonstrate the value of villagers' recall data in establishing stylized facts about how rural public services and land rights vary across space and time. In future work, this type of data could also be used to analyze causal effects of public services and institutions on economic outcomes. For example, Besley (1995) and others have found evidence that institutions significantly affect investment outcomes in rural Africa; Pande and Udry (2006) provide a summary of these studies. In Burkina Faso, Kazianga and Masters (2002) found that stronger cropland tenure was associated with more intensive soil and water conservation. Our approach to changes in village-level infrastructure and institutions is also relevant to the mechanisms by which large-scale public health interventions influence economic development, as in Acemoglu and Johnson (2007), Bleakley (2007) and Cutler et al. (2010).

In the next section, we describe the major exogenous population shifts that might permit identification of how changes in rural demography affect public goods provision. We then turn to our empirical strategy and a description of our data. In section four we present and discuss our results. Section five concludes.

\section{Historical Background}

Since independence in 1960, Burkina Faso has experienced two major policy-induced changes in settlement patterns. The first began in 1974 when the Onchocerciasis Control Program (OCP) was launched by the World Bank to control river blindness in seven West African countries: Benin, Burkina Faso, Cote d'Ivoire, Ghana, Mali, Niger, and Togo. The 
second occurred from the late 1990s until 2002 when up to one million Burkinabe returned from Cote d'Ivoire to escape violence and a suspension of immigrants' rights in that country. Since our ability to draw a causal link between population growth and institutional change hinges on these two events, we describe them in more detail below.

The OCP is widely considered to be among the most successful public health programs ever launched in Sub-Saharan Africa. Onchocerciasis, or "river blindness", is primarily a rural disease that affects Sub-Saharan Africa more than anywhere else in the world. The disease is spread through bites from black flies of the genus Simulium, which transmit the larvae of a filarial worm, Onchocerca volvulus. The worms multiply only in the human body, where they cause debilitating symptoms that include blindness, and are transmitted only by the black fly, which lives in proximity to fast-moving rivers. The OCP was a multilateral effort that initially covered eleven countries, including Burkina Faso. The program involved weekly aerial treatment and ground-level treatment of black fly breeding grounds. Annual drug treatments offered immediate relief from the symptoms and elimination of nearly all offspring of the adult worm.

Figure 2 provides a map of Onchocerciasis prevalence in and around Burkina Faso prior to the OCP, and afterwards. Prevalence rates were recorded at above $60 \%$ of surveyed people living in the lower Volta River valley before the OCP, which almost completely eradicated the disease in target countries but left prevalence rates unchanged in Sierra Leone. Eradication was incomplete in Guinea, Togo and Benin. Today, the disease is no longer considered a threat in the original control zone, which has consequently attracted in-migration from other rural areas.

Anticipating in-migration to newly attractive river valleys, the government of Burkina Faso created a special national agency — the Volta Valley Authority (AVV) — and gave the agency control of $75 \%$ of the targeted river basins. Figure 3 shows these locations, and the "planned" villages to which it provided financial and institutional support. However, the pace of spontaneous settlement soon outgrew the ability of the AVV to finance and create sufficient numbers of sponsored settlements. As a result, there were sizable intra- and interregional migration flows as documented by McMillan et al. (1992), typically from the drier northeast and central plateau to lower altitude river valleys, leading to the actual pattern of inter-regional migration illustrated in Figure 4, from McMillan et al. (1993). 
Figure 4 documents the pattern of human migration that occurred in the late 1970s and 1980s. The arrows in the figure originate in the area of out-migration and the direction of movement. Dashed arrows indicate net human migration, while solid arrows indicate the path of transhumant (seasonal) livestock movements which formed travel corridors for migrants. The shading in the figure indicates how heavy the degree of net settlement was by province. This pattern of rural-to-rural migration reflected the economic opportunities opened up by river blindness control in the lower parts of the Volta River valleys, relative to the extreme poverty experienced in high density, higher-altitude areas with less disease pressure prior to the OCP. Figure 5 illustrates how, during colonial times, population had accumulated upstream in the Central Plateau, leaving the downstream segments of the three Volta River valleys with extremely low population densities. Some of population movement towards these downstream river valleys was planned as part of the OCP, but by 1983 more than 80 percent of the increase in cultivated land in Burkina's river basins could be attributed to spontaneous settlers (McMillan et al, 1993).

Also notable and of particular importance for our study is the fact that the lower parts of the Volta River valleys that attracted heavy in-migration are relatively accessible from Cote d'Ivoire. The domestic migration triggered by the OCP was therefore compounded by repatriation of migrants from Cote d'Ivoire, who converged on the same newly habitable provinces in southern Burkina Faso. Some of this return migration from Cote d'Ivoire could have happened as early as the mid-1980s due to changes in cocoa prices that made migration to Cote d'Ivoire less profitable than it once had been. Repatriation then accelerated sharply in the 1990s due to political changes in Cote d'Ivoire. After the death of the autocratic ruler Felix HouphetBoigny in 1993, his successor Henri Konan Bedie introduced the concept of "Ivorian-ness" in 1995, allegedly to deny Ivorian citizenship to his main political rival, Alassane Ouattara, thereby excluding him from office. Bedie insisted that Ouattara, a Muslim from the north of the country, was Burkinabe. Subsequently, attacks on people of foreign descent became increasingly widespread (Human Rights Watch 2001). By that time, more than one quarter of Cote d'Ivoire's population consisted of immigrants who had arrived since independence, of whom the overwhelming majority had come from Burkina Faso. As shown in Figure 6, the Cote d'Ivoire census of 1998 identified about 2.25 million Burkinabe living in Cote d'Ivoire, which was close 
to $20 \%$ of Burkina's total population at that time. Four decades of peace and stability in Cote d'Ivoire came to an abrupt end on December 24, 1999, when the military, under the leadership of General Robert Guei, overthrew the elected government of Konan Bedie in the country's first coup d'état. Although the coup was ostensibly prompted by soldiers' unhappiness over pay and conditions, it soon became apparent that, like Bedie, General Guei was also ready to incite ethnic and religious rivalries in order to remove political opposition. Continuing the theme of "Ivorianness", Guei introduced even stricter eligibility requirements for the 2000 presidential elections, once again excluding Alassane Ouattara on the basis of his alleged links with Burkina Faso.

Though exact numbers are difficult to come by, it is estimated that between 1999 and 2002 hundreds of thousands of Burkinabe were repatriated as a result of political unrest and worsening economic conditions in Cote d'Ivoire. They returned by rail, road, and on footpaths. Because of a lack of data, it is impossible to determine exactly where all of these emigrants decided to settle. But it is unlikely that many of them went back to the same impoverished Central Plateau they had originally fled. Much more likely is that these emigrants settled in the OCP river basins closer to Cote d'Ivoire, as suggested by McMillan et al. (1993).

\section{Empirical Strategy, Data, and Descriptive Statistics}

Our evidence on village-level access to public services, infrastructure and institutions comes from a novel survey conducted for this project by the Burkina Faso Office of Agricultural Statistics in January through June 2010. This survey asked groups of village elders to discuss and describe the history of the facilities around them, recording the date of any changes in the distance to each kind of facility and any changes in property-rights arrangements. From those underlying observations, we construct a time-varying index of the village's proximity to public services, public infrastructure, religious services, and markets, as well as time-varying indicators of property rights over land. We combine these indexes with population estimates for each village from the Burkina Faso national censuses of 1986, 1996, and 2006 to test whether crosssectional and time-series variance in population size can help explain variance in the provision of public services, infrastructure, market institutions and property rights. To help identify a causal effect of demographic change on our outcome variables, we use the exogenous pressures on population described in the previous section. 
The survey instrument is provided in the appendix. It was administered by experienced enumerators employed for Burkina's annual agricultural survey, the structure of which is designed to accommodate new survey modules. The enumerators began by assembling a focus group of village elders and officials who were asked a series of detailed questions regarding various types of public services, infrastructure, and institutions available to them. For each type of public-sector amenity, we asked how far villagers had to travel to reach the nearest point of service, at present and in previous years, along with the date of any change. The section on property rights did the same for institutions, for example by posing the following question: Can land be sold in your village? If the group agrees that the answer to this question is yes, the interviewer then asks: since when could land be sold in your village? Questions posed in this way allow us to construct time varying indexes over multiple amenities from the point of view of the villagers themselves. Our results focus on two kinds of variables: travel distances to public services or infrastructure, and categorical indicators of land use rights, both as reported for each census year.

The travel distances to collective amenities are grouped into four categories: (1) Public Services and Utilities, defined as the administrative office used to register births, any savings and loan facility, any fixed-line telephone, or any mobile phone reception; (2) Public Infrastructure, defined as a road that is accessible by truck all year, a road accessible by truck seasonally, a bus stop, a primary school, a secondary school, or a health center; (3) Religious Services, defined as any church, mosque, or temple; and (4) Markets, defined as any market with storage facilities, any livestock market, or a private shop. These are all the distances for which our groupinterview technique elicited unambiguous agreement in at least 700 of the 730 villages. Other questions, such as distance to water wells, bridges and electricity supplies, elicit agreement less often, perhaps because those amenities are less salient to villagers' lives or their use is more varied among the respondents. The distances to collective amenities were then aggregated in each of three ways. First, we consider the distance one must travel to have access to all the services in a given category, i.e. the distance associated with the farthest one. Second, we consider the average distance to all of the services in the group, i.e. the arithmetic mean of each distance. Finally, we consider the distance to any of the listed services, i.e. the minimum distance among them. 
Categorical indicators of land rights address three kinds of land use. First, we ask whether use rights over crop land are undefined or held by individuals, families, or the community. Then we ask whether cropland had ever been rented or sold, which we take to indicate the presence of a land market. Finally, we ask whether villagers recognize a formal authority that regulates access to pasture land, forests and potentially cropped land.

Our sample of villages consists of 747 sites that had previously been selected by the Office of Agricultural Statistics for their nationally representative agricultural survey conducted annually since the early 1990s. In this context, villages are very small, averaging about 1,500 people. Their boundaries can change somewhat from decade to decade, as some households enter or split off to form new settlements associated with the village. Our final dataset consists of 730 villages whose recorded names are the same across the three censuses and our new survey, at a correctly recorded GIS location. We use year and region fixed effects for each of Burkina's 45 provinces in order to focus on spatial variation across villages within relatively small administrative units, as well as village fixed effects to control for time-invariant village characteristics not included in our dataset.

Table 1 presents the proportion of all observations with each category of property right, as reconstructed for the census years of 1985, 1996 and 2006. For example, rights over cropland are not defined in 14.4 percent of village-year observations, implying a complete absence of rule of law over this resource. Ten percent of observations involved cropland rights controlled by communal authorities, almost 60 percent had cropland rights held by families, and almost 16 percent reported cropland rights held by individuals. Descriptive statistics on all variables as used in the regressions are provided in Table 2, separately for each year to reveal the time trends. Public services become more closely available and property rights are more tightly regulated in more recent years. Also, note that the average population of all surveyed villages grows from 1985 to 1996 , but then falls in 2006. There is likely to have been systematic undercounting of the rural population in 2006, which is why the Burkina government is planning a new census several years ahead of its decennial schedule.

To overcome endogeneity between a village's amenities and its population size, we instrument the village's population by its straight-line distance to any river from which Onchocerciasis could have been eradicated. We expect distance to the river to be inversely 
correlated with population size in all survey years (1985, 1996 and 2006), as households moved into the river valleys after 1974. To account for time-varying migration and population growth as well as differences in enumeration and the quality of each census, we interact distance to river with period dummies to allow for differential effects over time. The advantage of using this instrument to proxy for demographic factors associated with river blindness control is that it is "clean", and not influenced in any way by administrative boundaries or ex-post classifications that might drive correlations with infrastructure, public services or land use. This strategy does have some disadvantages, of course: distance to rivers may turn out to be a weak instrument for population size, and it may not be valid to exclude distance to river from our main regression if infrastructure, public services and land rights are correlated with distance to rivers independently of its influence on population size. As a result, we may not be able to interpret our estimated coefficients on instrumented population as a causal effect of population change alone. The coefficients and significance levels, even in our IV regressions, remain correlations that could confound the effects of population size with other features of proximity to rivers that might repel or attract people and also influence infrastructure, public services and land rights.

One way to test the degree to which exogenous OCP treatment made river valleys newly attractive to people, and whether the resulting demographic change was associated with any political response in terms of infrastructure, public services and land rights, is to split the sample into treatment and placebo regions. Inside treatment regions, the OCP made village locations nearer river valleys newly attractive after 1974. In the placebo regions, the relative attractiveness of proximity to rivers did not change. To demarcate the OCP-treated regions shown in Figures 2, 3 and 4, we use the province boundaries shown in Figure 4 around the shaded, migrant-receiving areas. These provinces contained land that became newly attractive over time, presumably because the black flies that transmit Onchocerciasis were eliminated after 1974.

The empirical strategy we use results in a set of two-stage least squares (2SLS) regressions, asking whether demographic changes associated with the attractiveness of a village's proximity to rivers are correlated with the spread of rural public services, infrastructure, and market institutions serving that village. Our paper does not identify the mechanism by which more populated villages might obtain more rural public services, infrastructure, or market institutions: instead, our goal is to test whether our new type of data can reveal an informative 
relationship, exploiting an unusual natural experiment in the relative attractiveness of village locations across Burkina Faso.

\section{Estimating Equations and Results}

Our estimation begins with a set of descriptive OLS regressions showing the correlations between village-level population and public infrastructure or institutions, controlling for year and province fixed effects, using the following specification:

$$
I_{j k}=\alpha+\beta P_{j t}+\delta X_{j}+\gamma_{t}+\varepsilon_{j k t}
$$

where $I$ is our measure of infrastructure or institution of type $k$ serving village $j$ at time $t$ from the survey data, and $P$ is our measure of the total population in village $j$ at year $t$ from the census data, and $\gamma$ are time dummies. $X$ controls for province fixed effects, and in robustness tests also controls for the ethnic composition of village population. Our hypothesis is that that $\beta>0$, as larger populations facilitate the provision of public goods and market institutions, due either to relative scarcities as in Boserup (1965) or to indivisibilities at the relevant scale of population size.

Estimates of regression (1) are shown in table 3, where $X$ controls only for province fixed effects. Columns 1-12 all concern the presence of public services. In columns 1-4 the dependent variable is the maximum distance one must travel to have access to all amenities in each category. In columns 5-8, the dependent variable is the average distance one must travel to access any amenity in each category, and in columns 9-12 the dependent variable is the minimum distance one must travel to access at least one of them. Both the distances and village population are expressed in natural $\log$, so that the coefficients can be interpreted as elasticities. We find that larger villages have closer amenities in 11 of the 12 regressions; the one exception is column (2), where only the time trend is significant.

Columns 13-19 refer to land rights. The dependent variable takes the value of 1 if our respondents report that this type of land-use rights is used in the village, and 0 otherwise. Because our model contains province or village fixed effects, we estimate the relationship between population and land rights using a linear probability model. Coefficients can be interpreted as the change in the probability that a certain type of land right exists when the 
natural log of population increases by 1 . In a larger village, land ownership is less likely to be familial (as opposed to individual or communal), but the more important correlation is with the presence of land market transactions: having a larger village population by 1 log point is associated with a $1.9 \%$ higher probability of having had land transactions.

Table 4 repeats the diagnostic OLS regression with additional controls for the number of land chiefs who participated in the group interview, as well as the number of ethnic groups and number of clans reported to be present in the village, as a crude approximation of the village's social fragmentation which might influence political cooperation and collective action for public goods provision (e.g. Alesina and La Ferrara 2005). The correlation between population size and access to public goods is usually but not always robust to these controls. Estimated coefficients on population size are somewhat smaller when controlling for ethnic diversity and number of land chiefs, but contrary to some hypotheses the more diverse villages actually have more public infrastructure than the less diverse ones. In the absence of any clear identification strategy regarding fragmentation, however, for this paper we focus on the main relationship concerning total population size.

Finding significant coefficients in these OLS regressions is not surprising, as people could choose to locate in villages with closer access to public institutions and services, or both could be caused by something else. To overcome endogeneity, we use instrumental variables for population, so that the only variation in village population used in our second stage regression will be associated with distance to rivers and changes over time.

The first stage regression of our 2SLS system is specified as follows:

$$
P_{j t}=\alpha_{0}+\alpha_{1} R_{j}+\alpha_{2} T_{t} R_{j}+\alpha_{3} T_{t}+\alpha_{4} M_{j}+\epsilon_{j}
$$

where $R$ is the log of geographic distance to the nearest river in village $\mathrm{j}, T$ are year dummies for 1996 and 2006, and $M$ is controls imposed through province or village fixed effects. When using the resulting predicted village populations, the coefficient estimate from equation (1) could be interpreted as a causal effect of population size only if a village's distance to rivers had no other channel of influence on the provision of public services and land rights. Our goal in this paper is simply to test whether such a link exists; if so, the mechanism could be addressed in future work. 
Any correlation between a village's population and its distance to rivers might vary over time, so the first stage regression includes time dummies and interaction terms. The OCP started in 1974 and our observations are in 1985, 1996 and 2006, so we expect that distance to rivers might be most important for population in the earlier years. We also expect that distance to rivers might matter more in the regions where OCP had been active, so we divide the sample between villages in the treatment provinces and villages in placebo regions where this shock did not occur.

First stage results are shown in Table 5. Columns 1-3 use province fixed effects, for the country as a whole and then for the placebo and treatment regions only. Columns 4-6 do the same using village fixed effects. The point estimates in row one indicate that villages further from rivers are significantly smaller: a one percent increase in travel time to a river reduces village population size by 0.247 percent. The magnitude of this effect is roughly twice as large for villages in the Volta Valley region as it is for villages outside this region. The interaction terms in rows 4 and 5 indicate that the influence of distance to river on population size did not diminish significantly between 1985 and 1996 and thus the difference between treatment and control group persists. In 2006, however, the coefficient on the interaction term is positive and significant for the entire sample and is driven by the treatment group. Taken together, the point estimates on distance to river of -0.312 and distance to river interacted with the year dummy for 2006 of +0.27 imply that in 2006 , a one percent increase in the distance to a river reduces the population size by 0.047 percent in the treatment villages. This result is consistent with our expectation that the size of the effect would diminish over time. Beneath each column, we provide an F-statistic on the joint significance of all instruments. The null hypothesis that the instruments are jointly irrelevant in the regression can be rejected at the one-percent level for all cases. Additionally, the F-statistics meet the rule of thumb cut-off suggested by Stock and Yogo (2005) in five of six cases (all but the last column), which is an indication of the explanatory power of our instruments.

Tables 6.1-6.6 report our instrumental variable (IV) estimates, using the same sequence of regressions as shown in Table 3 using OLS. Below each column of Table 6, we report the 2SLS regression's Hansen J statistic and the associated p-value. The p-values are generally well 
above 0.10 indicating that we cannot reject the null hypothesis that our excluded instruments are uncorrelated with the error term in most instances.

It is notable that the IV coefficients on village population are generally larger and more significant than the OLS estimates in Table 3. A potential explanation is that the OLS estimates reflect the average population effect on the outcomes variables (e.g Card 1995, 2001). On the other hand, the IV estimates reflect the effect of population in villages where the instruments induced population changes (Imbens and Angrist 1994).

Table 6.1 shows our basic result with province fixed effects, for the entire country. Variation in a village's population associated with proximity to rivers is positively associated with having more public services, infrastructure, religious facilities, and markets, as well as more individual land rights (as opposed to familial or communal), more land rental or sale transactions, and regulated access to forest land. The only unexpected coefficient is in column 19 , showing less regulated access to crop land, but that is only weakly significant and arises in the context of column 13 indicating rights are more likely to be vested in individuals than in families or communal authorities.

Table 6.2 shows the same regression with village fixed effects. Coefficients for public services, religious facilities, and land regulations are no longer significant, but the coefficients on infrastructure, markets, individual land rights and land markets remain large and significant. These amenities show the strongest link to village population changes over this 20 -year time period, controlling for common national time trends and any time-invariant characteristics of the villages other than their population.

Tables 6.3 and 6.4 show the corresponding pair of results for the Volta Valley region only, first with province and then with village fixed effects. Here coefficients are generally larger, but significance levels are sometimes smaller perhaps due to the smaller sample size. With village fixed effects, two of the three infrastructure variables and also individual land ownership rights and land markets remain significantly linked to instrumented population size.

Tables 6.5 and 6.6 show the relevant results for the villages outside our treatment region. This is a type of placebo regression, although in this case we do not expect the link between population and public services to disappear entirely. Indeed in these non-treatment villages, the coefficients on instrumented population remain significant for religious facilities and a few other 
amenities when using province fixed effects, although even these become insignificant when village fixed effects are used.

So far, we have shown that variance in village population is robustly correlated with the provision of local public services, private markets and individual property rights. The link is particularly clear when instrumenting population by proximity to rivers, especially within the Volta Valley where the OCP shock occurred. This correlation between village population and public amenities could be driven by various possible mechanisms to be investigated in future work, including scale economies in the public sector and the relative scarcity of natural resources.

Whatever mechanisms are involved, the magnitude by which larger villages obtain more public services and also have more access to private markets and individual land rights is economically significant. The order of magnitude can be described by comparison to the time trends sweeping Burkina Faso as a whole, driven by national policy and other changes. The point estimates of elasticities reported in Table 6.1 give us the effect of a $1 \%$ increase in village population, which we can compare to the effect of time associated with our dummy variables for 1996 and 2006. For example, using column 2 for proximity to every item of public infrastructure (including the farthest), villages that are one percent larger in terms of population size have infrastructure that is 0.32 percent closer. In contrast, the time trend for new infrastructure projects improved their proximity by 16 percent and 74 percent from 1985 to 1996 and 2006 respectively. Over a 10 year period, village population is likely to increase by much more than one percent. For example, using the average rural population growth rate of 2 percent, village population would increase by 25 percent. The implied reduction in travel distance to public infrastructure is $0.32 * 25$ or 8 percent. Alternatively, a doubling of village size is roughly equivalent to a decade or two of time trend for most of the variables we consider.

\section{Conclusion}

This paper uses variance in rural demography associated with proximity to rivers in Burkina Faso to test whether villages with larger populations obtain closer provision of public services, public infrastructure, religious facilities and markets, and have more market-oriented property rights over land use. Our data on infrastructure and institutions come from a new survey of 
village elders, which was designed to document change over time and differences across villages. We find strong links between larger rural population, more local public goods provision and individual property rights, controlling for either province or village fixed effects and time trends.

One feature of our study is to demonstrate the use of village elders' recall data in constructing time-varying indexes of local infrastructure and institutions. This involves asking about villagers' access to specific amenities, and then aggregating those responses into indexes that capture variation in public amenities from their point of view. The correlations we find demonstrate the potential significance of this approach as a way to overcome the limited availability of other ways to measure variation in public services, infrastructure, and institutions over time and space.

In the particular setting of rural Burkina Faso, we find that variance in village population size is significantly correlated with village-level access to infrastructure, markets and individual land rights. These public amenities are clearly of great importance for rural development. Future work using our data or similar new surveys elsewhere could document further how village infrastructure and institutions are responding to Africa's extraordinary demographic changes, and explore the economic mechanisms behind these important political changes. 


\section{References Cited}

Acemoglu, Daron and Simon Johnson, 2007. "Disease and Development: The Effect of Life Expectancy on Economic Growth." Journal of Political Economy, 115(6): 925-985.

Besley, Timothy, 1995. "Property Rights and Investment Incentives: Theory and Evidence from Ghana." The Journal of Political Economy, 103(5): 903-937.

Bleakley, Hoyt. 2007. "Disease and Development: Evidence from Hookworm Eradication in the American South." The Quarterly Journal of Economics, 122(1): 73-117.

Bloom, David E. and Jeffrey G. Williamson, 1998. "Demographic Transitions and Economic Miracles in Emerging Asia.” World Bank Economic Review 12(3): 419-455.

Boserup, Ester, 1965. The Conditions of Agricultural Growth: The Economics of Agrarian Change under Population Pressure. London, G. Allen and Unwin, 1965.

Card, David. 1995. "Earnings, Schooling, and Ability Revisited." In Research in Labor Economics, volume 14, Editor Solomon Polachek, Greenwich Connecticut: JAI Press, 23-48.

Card, David. 2001. "Estimating the Return to Schooling: Progress on Some Persistent Econometric Problems." Econometrica, 69(5): 1127-1160.

Chambers, Robert, 1994. "The origins and practice of participatory rural appraisal." World Development, 22(7): 953-969.

Chattopadhyay, Raghabendra and Esther Duflo, 2004. "Women as Policy Makers: Evidence from a Randomized Policy Experiment in India," Econometrica, 72(5): 1409-1443.

Comite International de Cooperation dans les Recherches Nationals en Demographie, 1999. "Dynamique de Peuplement Des Zones Rurales Liberees de l"Onchocercose en Afrique de l'Ouest, Synthese de Monographs Nationals, Coordination, Andre Quesnad.

Cutler, David, Winnie Fung, Michael Kremer, Monica Singhal, and Tom Vogl. 2010. "Early-Life Malaria Exposure and Adult Outcomes: Evidence from Malaria Eradication in India." American Economic Journal: Applied Economics, 2(2): 72-94.

Dovring, Folke, 1959. "The Share of Agriculture in a Growing Population," FAO Monthly Bulletin of Statistics 8(8).

Grimm, Michael and Klasen, Stephan, 2008. "Geography vs. Institutions at the Village Level". IZA Discussion Paper No. 3391. Bonn: IZA, 29 pages.

Hayami, Yuhiro \& Vernon W. Ruttan, 1971. "Agricuitural development: an international perspective.” Baltimore, MD: Johns Hopkins University Press.

Human Rights Watch, 2001. "The New Racism: Political Manipulation of Ethnicity in Cote d'Ivoire.” New York: HRW (August, 2001), online at www.hrw.org/en/reports/2001/08/28/new-racism.

Imbens, Guido and Joshua Angrist. 1994. "Identification and Estimation of Local Average Treatment Effects." Econometrica, 62(2): 467-475.

IRIN News, "In-depth: Cote d'Ivoire crisis" (November, 2002). Online at www.irinnews.org/IndepthMain.aspx?indepthid=38.

Jedwab, Remi and Alexander Moradi, 2011. "Transportation Infrastructure and Development in Ghana.” Paris School of Economics Working Paper No. 2011-24. Paris: PSE, 47 pages..

Johnston, Bruce and Peter Kilby, 1975. Agriculture and Structural Transformation. New York: Oxford University Press.

Kazianga, Harounan and William A. Masters, 2002. "Investing in soils: field bunds and microcatchments in Burkina Faso." Environment and Development Economics, 7: 571-591 
Kazianga, Harounan and William A. Masters, 2006. "Property rights, production technology, and deforestation: cocoa in Cameroon.” Agricultural Economics 35 (1): 19-26.

Lin, Justin Yu, 1995. "Endowments, Technology, and Factor Markets: A Natural Experiment of Induced Institutional Innovation from China's Rural Reform." American Journal of Agricultural Economics 77(2): 231-242.

Masters, William A. and Margaret S. McMillan, 2001. "Climate and Scale in Economic Growth," Journal of Economic Growth, 6(3): 167-186.

McMillan, Della E., Jean-Baptiste Nana and Kimseyinga Savadogo, 1992. "Adaptation of RAP to Monitoring Settlement Trends in Areas Covered by Successful Disease Control Programmes: Onchocerciasis", in N.S. Scrimshaw and G.R. Gleason, eds. Rapid Assessment Procedures: Qualitative Methodologies for Planning and Evaluation of Health Related Programmes. Boston, MA: International Nutrition Foundation.

McMillan, Della E., Jean-Baptiste Nana and Kimseyinga Savadogo, "Settlement and Development in the River Blindness Control Zone.” World Bank Technical Paper No. 200, Series on River Blindness Control in West Africa. Washington, DC: World Bank, 1993.

McMillan, Margaret, 2001. "Why Kill the Golden Goose? A Political-Economy Model of Export Taxation." Review of Economics and Statistics, 83 (1): 170-184.

McMillan, Margaret and William A. Masters, 2003. "An African Growth Trap." Review of Development Economics 7(2): 179-191.

Olmstead, Alan L. and Paul Rhode, 1993. "Induced Innovation in American Agiculture: A Reconsideration." Journal of Political Economy, 101 (1): 100-118.

Pande, Rohini and Chris Udry, 2006. "Institutions and Development: A View from Below," in Proceedings of the 9 th World Congress of the Econometric Society, edited by R. Blundell, W.Newey and T.Persson, Cambridge University Press.

Stock, J. H. and M. Yogo. 2005. Asymptotic Distributions of Instrumental Variables Statistics with Many Instruments in Identification and Inference for Econometric Models: Essays in Honor of Thomas Rothenberg, ed. D.W.K. Andrews and J.H. Stock. Cambridge: Cambridge University Press.

Temple, Jonathan R. W. (2005). "Dual economy models." The Manchester School, 73(4), 435-478. 
Figure 1. Past and projected rural population growth, by region and country (1950-2050)

Panel A: Regional aggregates

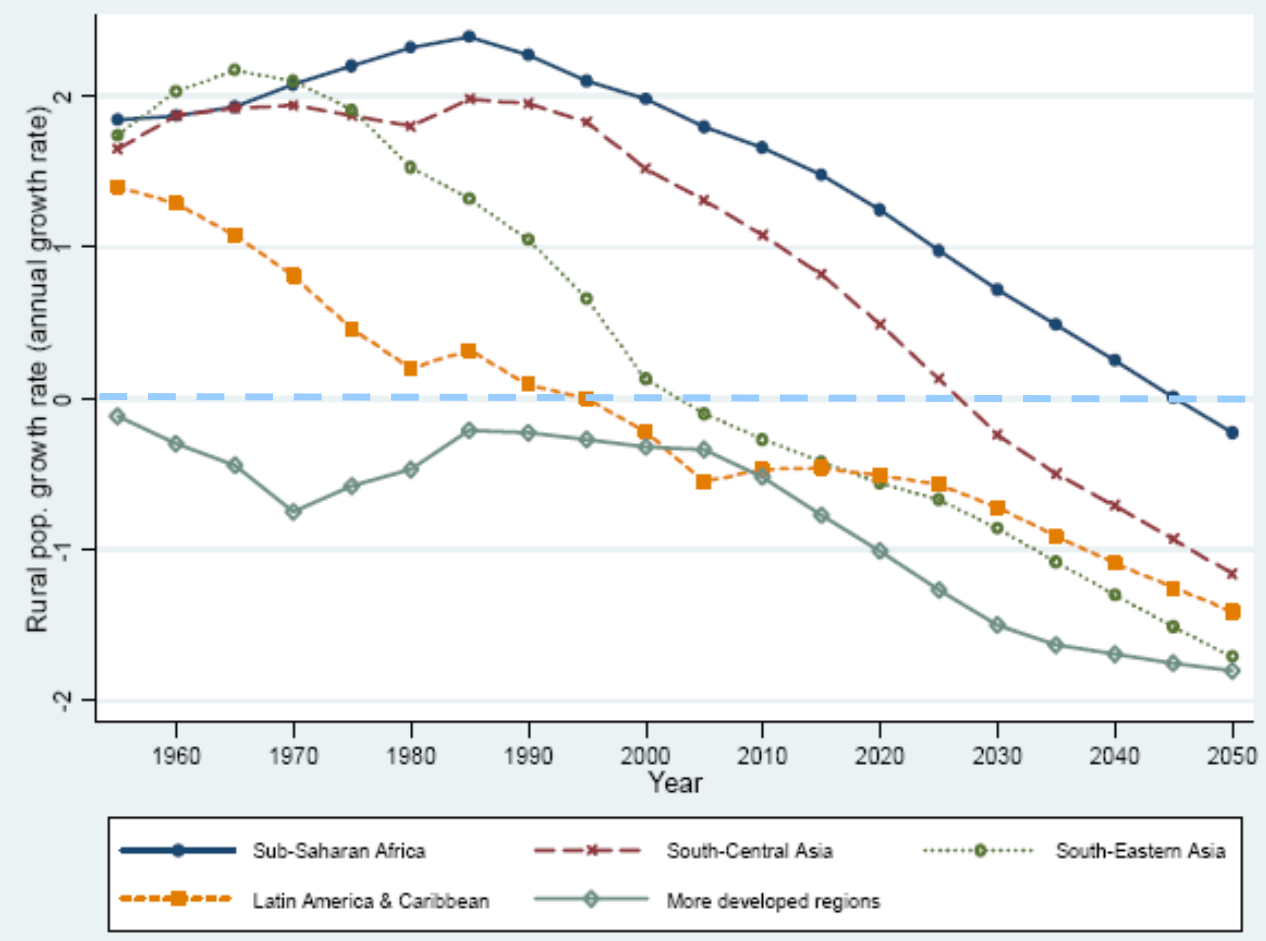

Zero rural

pop. growth

\section{Panel B: Burkina Faso}

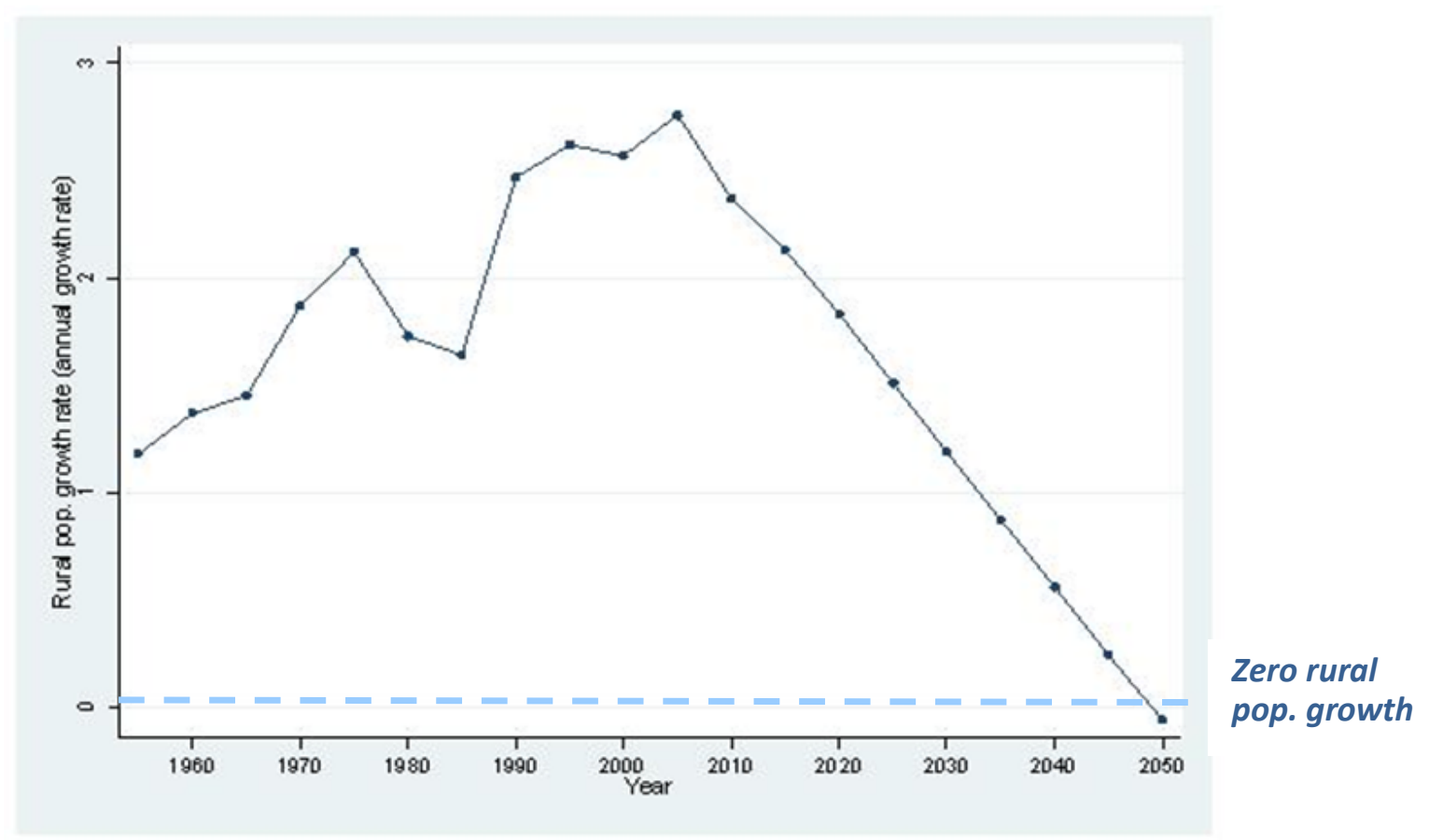

Source: Calculated from UN Population Projections (esa.un.org/unpp). 
Figure 2. Estimated Onchocerciasis Prevalence in West Africa

Panel (a): Prior to control (1974)

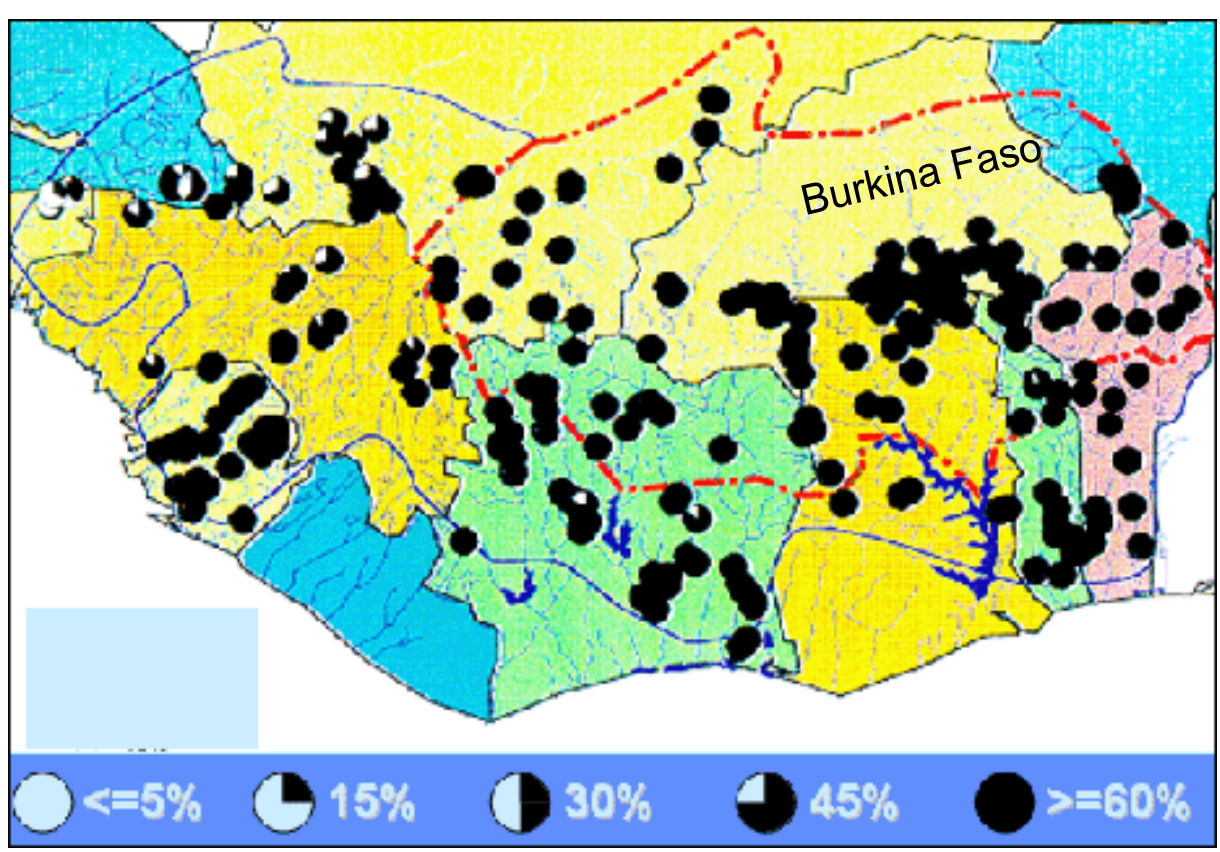

Panel (b): After control (2002)

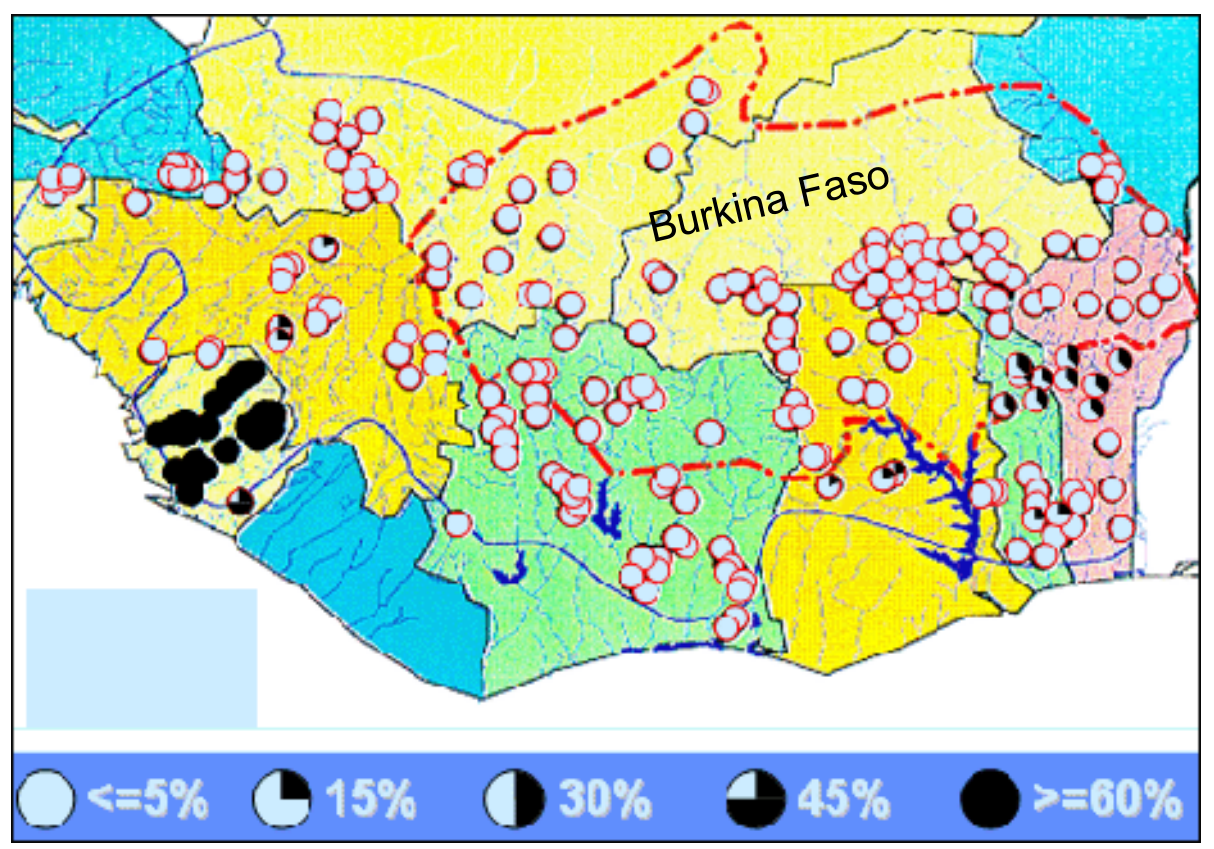

Source: WHO, Onchocerciasis Control Programme (www.who.int/apoc/onchocerciasis/ocp). 
Figure 3. Location of Planned Settlements Associated with Onchocerciasis Control, 1973-1984

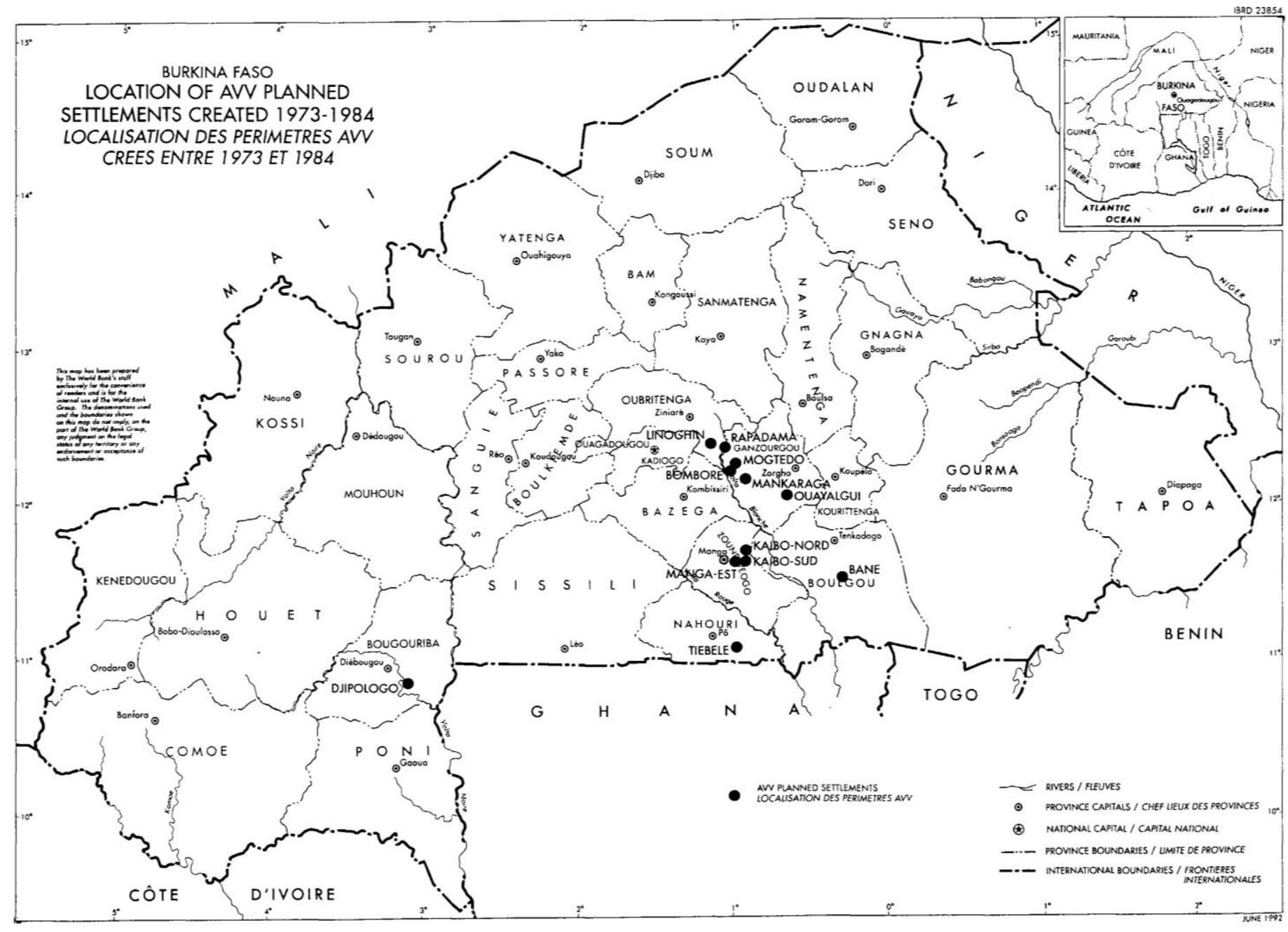

Source: Della E. McMillan, Jean-Baptiste Nana and Kimseyinga Savadogo, "Settlement and Development in the River Blindness Control Zone.” World Bank Technical Paper No. 200, Series on River Blindness Control in West Africa. Washington, DC: World Bank, 1993. 
Figure 4. Patterns of Agricultural Migration in Burkina Faso

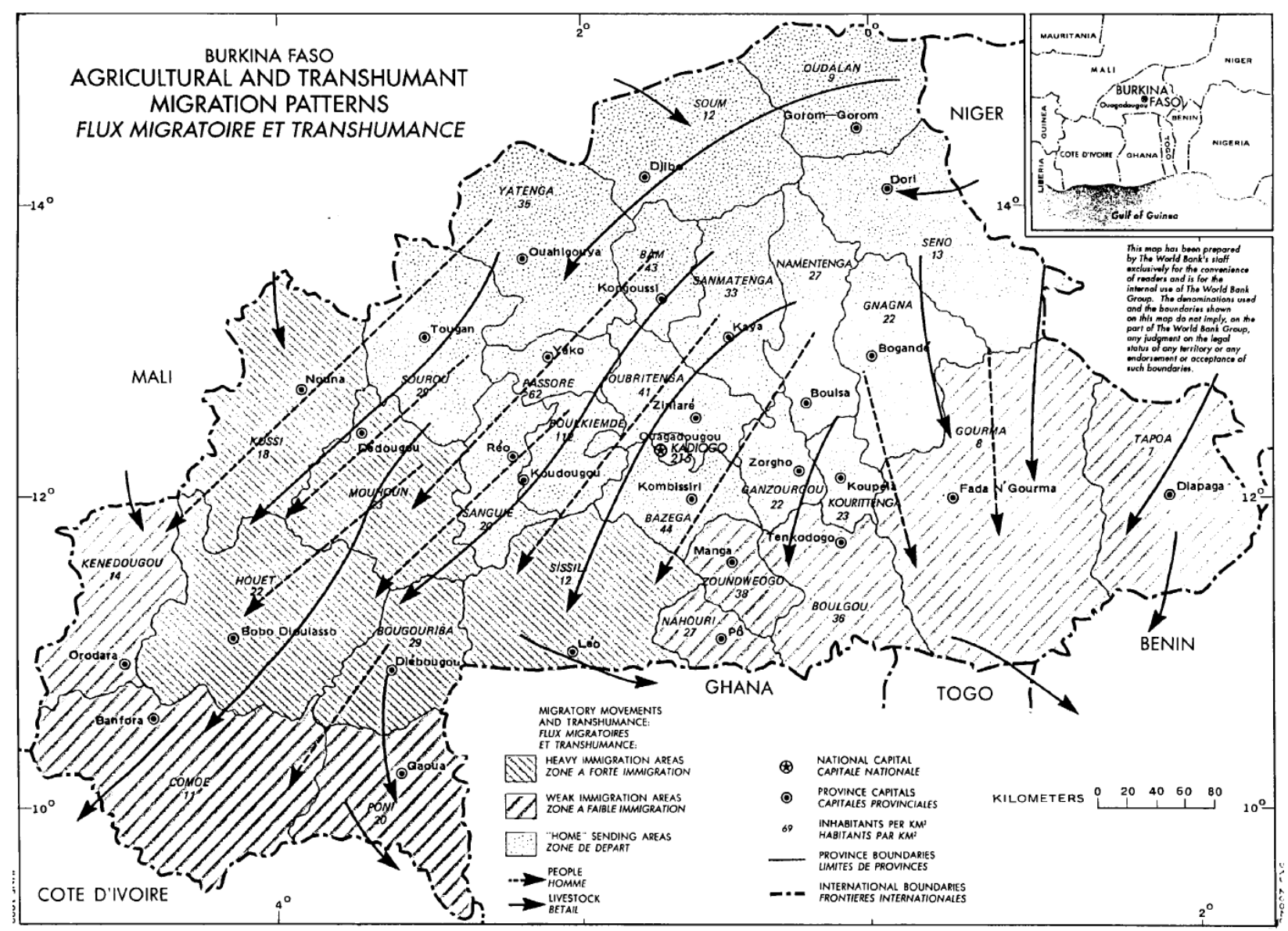

Source: Della E. McMillan, Jean-Baptiste Nana and Kimseyinga Savadogo, "Settlement and Development in the River Blindness Control Zone." World Bank Technical Paper No. 200, Series on River Blindness Control in West Africa. Washington, DC: World Bank, 1993. 
Figure 5. Population Density in Burkina Faso, 1960-61

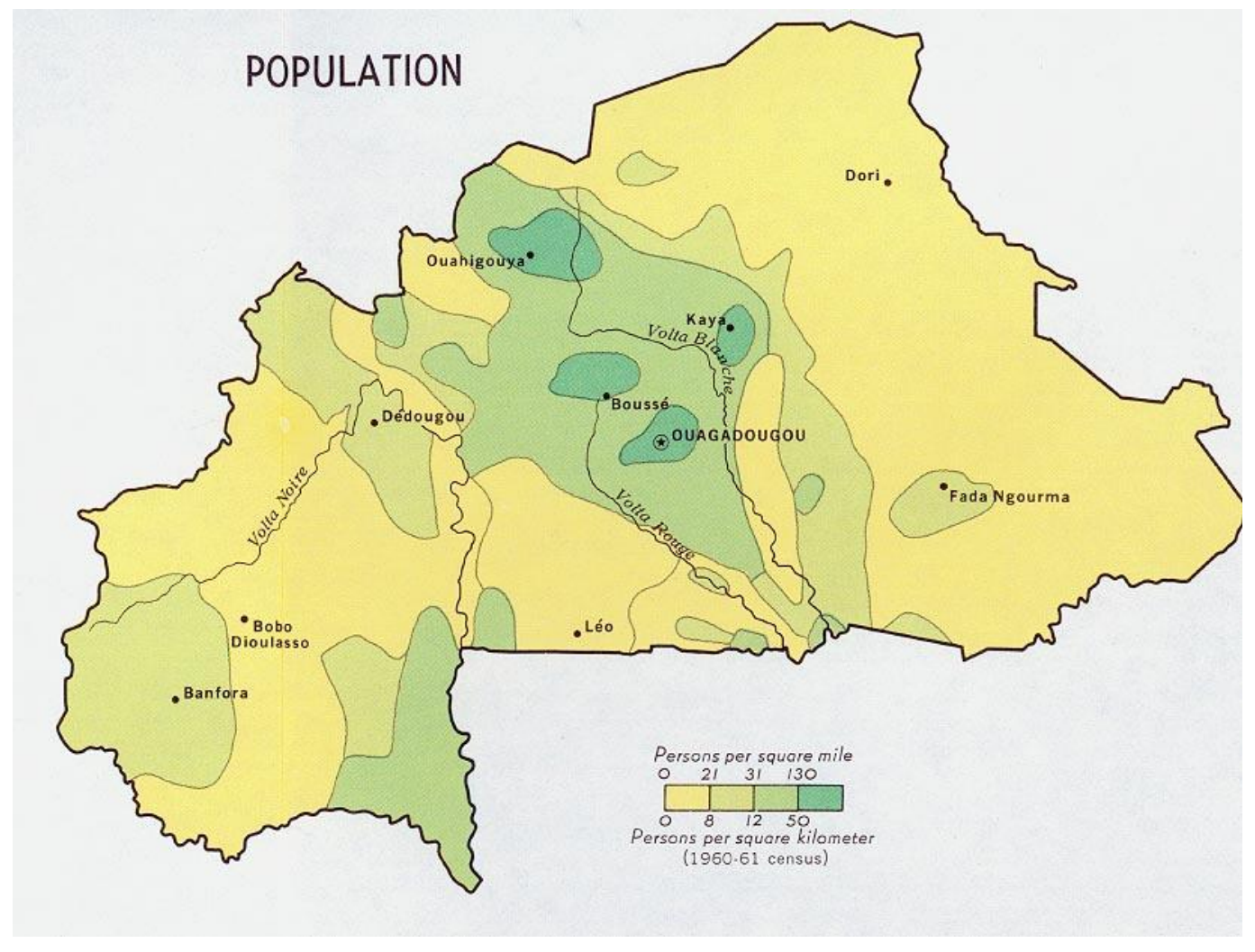

Source: University of Texas at Austin, Perry-Castañeda Library Map Collection, from U.S. Central Intelligence Agency Map No. 58207, 1968. Available online at http://www.lib.utexas.edu/maps/burkina_faso.html. 
Figure 6: Foreign Population in Cote d'Ivoire by Nationality, 1998 Census

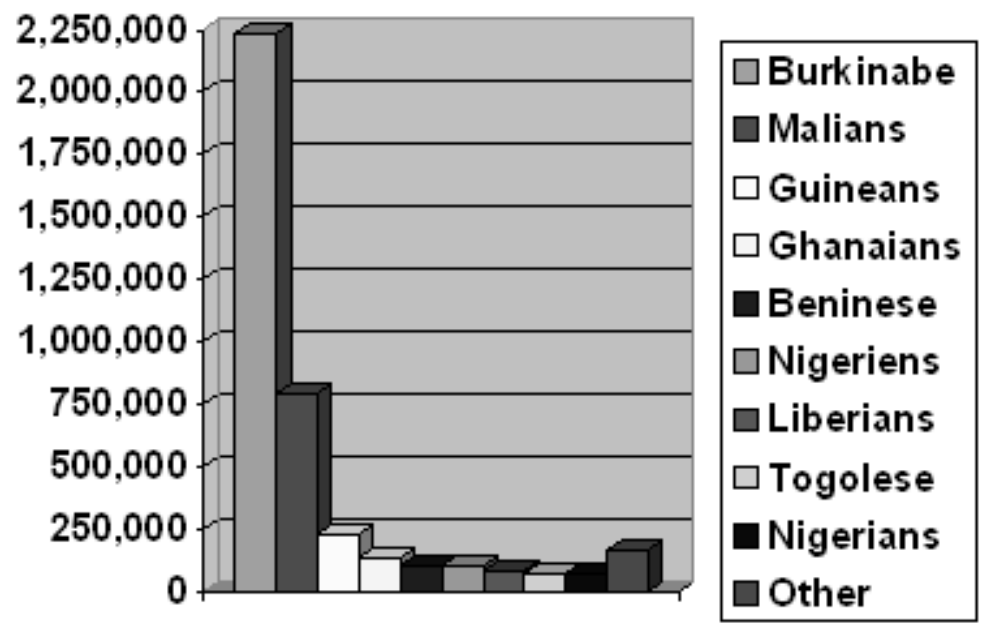

Source: IRIN News, "In-depth: Cote d'Ivoire crisis" (November, 2002). Online at http://www.irinnews.org/IndepthMain.aspx?indepthid=38. 
Figure 7: Location of Surveyed Villages and Rivers Used for IV Estimation

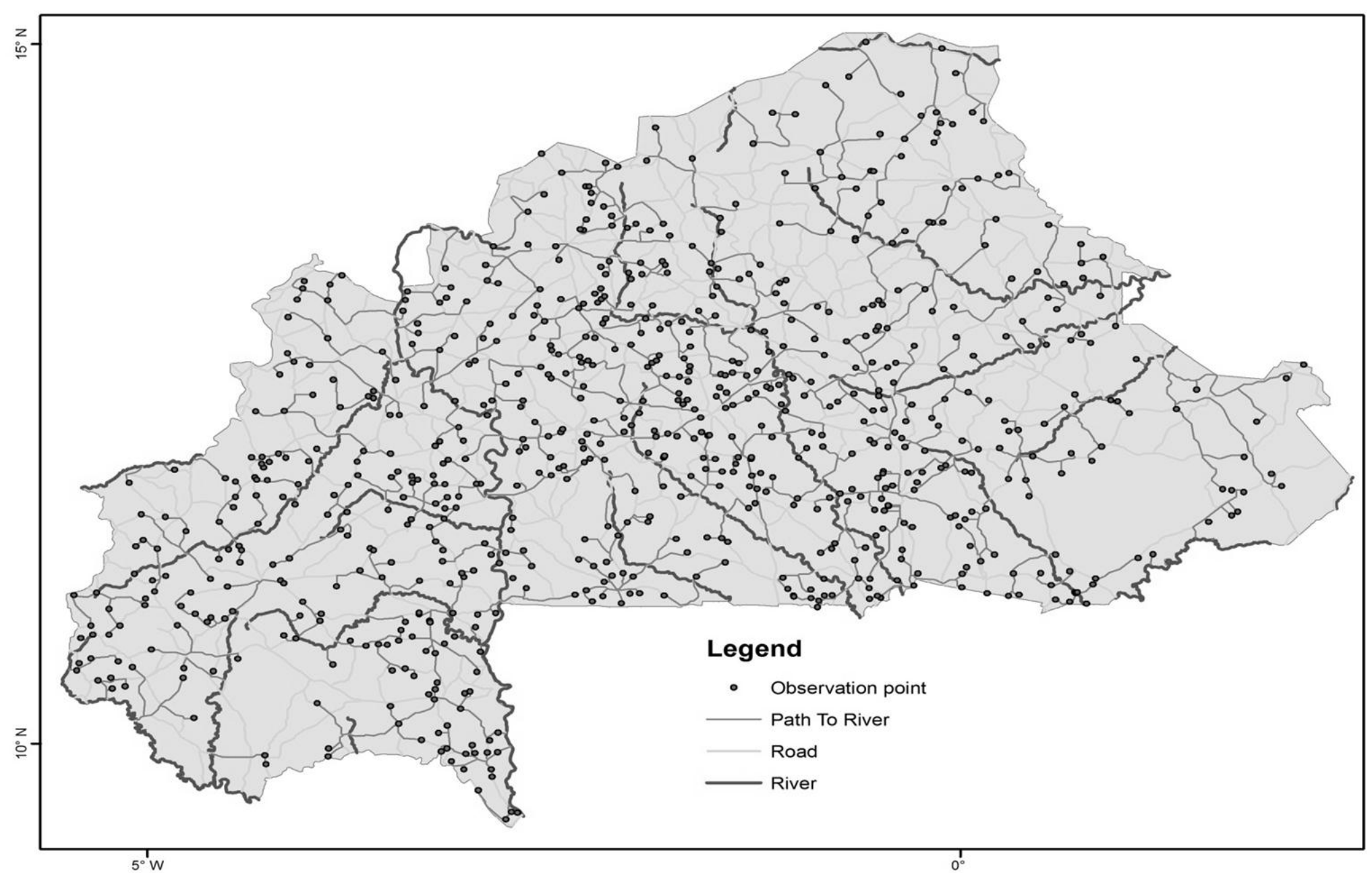

Source: Authors' calculations. Village locations are drawn from authors' survey data; river locations and paths from villages to rivers are calculated from IFPRI file data. Roads and travel paths are shown for illustration purposes only; data used for hypothesis tests are straightline distances from the village to the closest river, and travel distance to nearest point in Cote d'Ivoire (at the lower-left of the map shown). 
Table 1: Property rights and land use across sample villages in Burkina Faso ( $\mathrm{n}=2,076)$

\begin{tabular}{|c|c|}
\hline Land Rights & $\begin{array}{l}\text { Percentage } \\
\text { of } \\
\text { observations } \\
\text { in sample }\end{array}$ \\
\hline \multicolumn{2}{|l|}{ Rights over crop land } \\
\hline Not defined & 14.4 \\
\hline Communal & 10.0 \\
\hline Familial & 59.9 \\
\hline Individual & 15.7 \\
\hline \multicolumn{2}{|l|}{ Existence of sales or rental of crop land } \\
\hline None & 92.4 \\
\hline At least one sale or rental has occurred & 7.7 \\
\hline \multicolumn{2}{|l|}{ Role of traditional authorities in solving crop land conflict } \\
\hline None & 63.8 \\
\hline Some & 36.2 \\
\hline \multicolumn{2}{|l|}{ Role of elected authorities involved in solving crop land conflict } \\
\hline None & 81.9 \\
\hline Some & 18.1 \\
\hline \multicolumn{2}{|l|}{ Demarcation and regulation of pasture land } \\
\hline No delimited pasture land & 71.7 \\
\hline Pasture land delimited, access not regulated & 22.9 \\
\hline Pasture land delimited, access regulated by tax or quota & 5.4 \\
\hline \multicolumn{2}{|l|}{ Demarcation and regulation of forest land } \\
\hline No delimited forest land & 70.1 \\
\hline Forest land delimited, access not regulated & 15.9 \\
\hline Forest land delimited, access regulated by tax or quota & 14.0 \\
\hline
\end{tabular}

Source for all tables: Authors' calculations.

Notes: Results shown are from village elders' response to questions asked in local languages, translated by local enumerators from the French questionnaire reproduced in the appendix to this paper. Items shown are from questionnaire sections VIII (for crop land), IX (for pasture land) and $\mathrm{X}$ (for forest land). 
Table 2: Mean and standard deviations for all variables

\begin{tabular}{|c|c|c|c|c|c|c|c|c|c|c|c|c|c|c|}
\hline \multirow[b]{2}{*}{ Year } & \multicolumn{4}{|c|}{$\begin{array}{l}\text { Proximity of farthest source (km) } \\
\text { (Distance to farthest site in each set) }\end{array}$} & \multicolumn{6}{|c|}{$\begin{array}{l}\text { Proximity to all sources (km) } \\
\text { (Average distance to all services) }\end{array}$} & \multicolumn{4}{|c|}{$\begin{array}{l}\text { Proximity to closest source }(\mathrm{km}) \\
\text { (Distance to closest site in each set) }\end{array}$} \\
\hline & $\begin{array}{l}\text { Public } \\
\text { Services }\end{array}$ & $\begin{array}{l}\text { Public } \\
\text { Infrast. }\end{array}$ & $\begin{array}{l}\text { Religious } \\
\text { Services }\end{array}$ & Markets & $\begin{array}{l}\text { Pub } \\
\text { Servi }\end{array}$ & & $\begin{array}{l}\text { Publi } \\
\text { Infras }\end{array}$ & $\begin{array}{ll}\text { c } & \text { Relig } \\
\text { t. } & \text { Serv }\end{array}$ & $\begin{array}{l}\text { jious } \\
\text { ices }\end{array}$ & Markets & $\begin{array}{l}\text { Public } \\
\text { Services }\end{array}$ & $\begin{array}{l}\text { Public } \\
\text { Infrast. }\end{array}$ & $\begin{array}{l}\text { Religious } \\
\text { Services }\end{array}$ & Markets \\
\hline \multirow[t]{2}{*}{1985} & 35.348 & 35.458 & 9.27 & 12.832 & 26. & 915 & 14.66 & & 321 & 8.585 & 18.351 & 3.566 & 3.536 & 4.855 \\
\hline & [1.206] & [1.239] & {$[0.518$} & [0.790] & {$[0.7$} & 79] & {$[0.48$} & & 360] & [0.432] & [0.607] & [0.308] & [0.299] & [0.269] \\
\hline \multirow[t]{2}{*}{1996} & 35.635 & 28.053 & 7.465 & 12.735 & 25. & 055 & 11.53 & & .726 & 7.811 & 15.115 & 1.817 & 2.328 & 3.788 \\
\hline & [1.137] & [0.977] & {$[0.409$} & [0.741] & {$[0.7$} & 08] & {$[0.37$} & & 267] & [0.384] & [0.533] & [0.209] & {$[0.230]$} & [0.251] \\
\hline \multirow[t]{4}{*}{2006} & 32.151 & 20.955 & $5.21 \varepsilon$ & 11.455 & 19. & 681 & 8.09 & & .036 & 6.11 & 8.596 & 0.501 & 1.16 & 1.975 \\
\hline & [1.005] & {$[0.771]$} & {$[0.331$} & [0.611] & {$[0.5$} & 43] & {$[0.27 \varepsilon$} & & 194] & {$[0.276]$} & [0.415] & [0.083] & {$[0.138]$} & [0.176] \\
\hline & & & & & \multirow{2}{*}{\multicolumn{6}{|c|}{ Regulated access to land for: }} & \multicolumn{4}{|c|}{ Distance $(\mathrm{km})$ to: } \\
\hline & \multicolumn{4}{|c|}{ Land ownership rights } & & & & & & & \multirow{2}{*}{$\frac{\text { Population }}{{ }^{\prime}(1000 \mathrm{~s})}$} & \multirow{2}{*}{$\begin{array}{l}\text { Nearest } \\
\text { river }\end{array}$} & & \\
\hline Year & Indiv & jidual & Familial & Communal & $\underline{\text { markets }}$ & & isture & Forest & Crol & & & & & \\
\hline \multirow[t]{2}{*}{1985} & & 0.41 & 0.665 & 0.1 & 0.056 & & .152 & 1.353 & 2. & 75 & 1.6 & 65.986 & & \\
\hline & & 018] & [0.018] & [0.011] & [0.009] & & 013] & [0.024] & {$[0.03$} & & [0.058] & [1.782] & & \\
\hline \multirow[t]{2}{*}{1996} & & .423 & 0.671 & 0.099 & 0.064 & & .186 & 1.44 & 2.7 & & 1.682 & 66.876 & & \\
\hline & & 019] & [0.018] & [0.011] & [0.009] & & 015] & [0.027] & {$[0.03$} & & [0.059] & [1.818] & & \\
\hline \multirow[t]{2}{*}{2006} & & .453 & 0.669 & 0.104 & 0.107 & & 0.24 & 1.516 & 2.7 & & 1.396 & 66.336 & & \\
\hline & & 018] & [0.017] & {$[0.011]$} & [0.011] & & 016] & [0.029] & {$[0.03$} & & [0.091] & [1.777] & & \\
\hline
\end{tabular}

Notes: Standard deviations in brackets. Proximity measures refer to travel distances from the village to reach the closest site offering one or more of each set of collective resources: Public Services and Utilities (defined as the administrative office used to register births, any savings and loan facility, any fixed-line telephone, any mobile phone reception); Public Infrastructure (defined as a road that is accessible by truck all year, a road accessible by truck seasonally, a bus stop, a primary school, a secondary school, and a health center), Religious Services (any church, mosque or temple), and Markets (any open-air food market, livestock market, or private shop). Specific wording of each question is reproduced in the appendix; from the questionnaire as a whole, we retained only those proximity questions which more than 700 of the 730 villages were unable to answer unambiguously. Population is computed from the Burkina Faso national censuses for 1985, 1996 and 2006. Distances to nearest river are straight lines calculated from latitude and longitude geocodes. 
Table 3: OLS regression results for public infrastructure and institutions on village-level population

\begin{tabular}{|c|c|c|c|c|c|c|c|c|c|c|c|c|}
\hline & \multicolumn{4}{|c|}{ Proximity of farthest source $(\mathrm{km})$} & \multicolumn{4}{|c|}{ Proximity to all sources $(\mathrm{km})$} & \multicolumn{4}{|c|}{ Proximity to closest source $(\mathrm{km})$} \\
\hline & $\begin{array}{l}\text { Services } \\
\text { (1) }\end{array}$ & $\begin{array}{l}\text { Infrastr. } \\
\text { (2) }\end{array}$ & $\begin{array}{l}\text { Religion } \\
\text { (3) }\end{array}$ & $\begin{array}{c}\text { Markets } \\
\text { (4) }\end{array}$ & $\begin{array}{l}\text { Services } \\
\text { (5) }\end{array}$ & $\begin{array}{l}\text { Infrastr. } \\
(6)\end{array}$ & $\begin{array}{l}\text { Religion } \\
\text { (7) }\end{array}$ & $\begin{array}{c}\text { Markets } \\
\text { (8) }\end{array}$ & $\begin{array}{l}\text { Services } \\
\text { (9) }\end{array}$ & $\begin{array}{l}\text { Infrastr. } \\
\text { (10) }\end{array}$ & $\begin{array}{l}\text { Religion } \\
\text { (11) }\end{array}$ & $\begin{array}{c}\text { Markets } \\
\text { (12) }\end{array}$ \\
\hline Population & $\begin{array}{c}0.064 * * * \\
{[0.024]}\end{array}$ & $\begin{array}{c}0.013 \\
{[0.025]}\end{array}$ & $\begin{array}{c}0.226^{* * *} \\
{[0.031]}\end{array}$ & $\begin{array}{c}0.211 * * * \\
{[0.032]}\end{array}$ & $\begin{array}{c}0.067^{* * *} \\
{[0.021]}\end{array}$ & $\begin{array}{c}0.070 * * * \\
{[0.021]}\end{array}$ & $\begin{array}{c}0.217^{* * *} \\
{[0.026]}\end{array}$ & $\begin{array}{c}0.234^{* * *} \\
{[0.028]}\end{array}$ & $\begin{array}{c}0.128 * * * \\
{[0.031]}\end{array}$ & $\begin{array}{c}0.154^{* * *} \\
{[0.020]}\end{array}$ & $\begin{array}{c}0.187^{* * *} \\
{[0.023]}\end{array}$ & $\begin{array}{c}0.316^{* * *} \\
{[0.024]}\end{array}$ \\
\hline$Y=1996$ & $\begin{array}{c}-0.064 \\
{[0.054]}\end{array}$ & $\begin{array}{c}0.175^{* * *} \\
{[0.055]}\end{array}$ & $\begin{array}{l}0.125^{*} \\
{[0.069]}\end{array}$ & $\begin{array}{l}-0.015 \\
{[0.072]}\end{array}$ & $\begin{array}{c}0.016 \\
{[0.048]}\end{array}$ & $\begin{array}{c}0.187 * * * \\
{[0.046]}\end{array}$ & $\begin{array}{c}0.161^{* * *} \\
{[0.060]}\end{array}$ & $\begin{array}{c}0.043 \\
{[0.062]}\end{array}$ & $\begin{array}{c}0.177^{* * *} \\
{[0.058]}\end{array}$ & $\begin{array}{c}0.290 * * * \\
{[0.052]}\end{array}$ & $\begin{array}{c}0.210 * * * \\
{[0.055]}\end{array}$ & $\begin{array}{c}0.185^{* * *} \\
{[0.058]}\end{array}$ \\
\hline$Y=2006$ & $\begin{array}{c}0.040 \\
{[0.051]}\end{array}$ & $\begin{array}{c}0.487 * * * \\
{[0.055]}\end{array}$ & $\begin{array}{c}0.509 * * * \\
{[0.068]}\end{array}$ & $\begin{array}{c}0.085 \\
{[0.071]}\end{array}$ & $\begin{array}{c}0.261^{* * *} \\
{[0.046]}\end{array}$ & $\begin{array}{c}0.539 * * * \\
{[0.041]}\end{array}$ & $\begin{array}{c}0.526^{* * *} \\
{[0.058]}\end{array}$ & $\begin{array}{c}0.238 * * * \\
{[0.061]}\end{array}$ & $\begin{array}{c}1.093 * * * \\
{[0.065]}\end{array}$ & $\begin{array}{c}0 . .595 * * * \\
{[0.046]}\end{array}$ & $\begin{array}{c}0.486 * * * \\
{[0.052]}\end{array}$ & $\begin{array}{c}0.640^{* * *} \\
{[0.055]} \\
-\end{array}$ \\
\hline Constant & $\begin{array}{c}-3.643^{* * *} \\
{[0.164]}\end{array}$ & $\begin{array}{c}-3.261 * * * \\
{[0.174]}\end{array}$ & $\begin{array}{c}-3.175^{* * *} \\
{[0.219]}\end{array}$ & $\begin{array}{c}-3.275^{* * *} \\
{[0.225]}\end{array}$ & $\begin{array}{c}-3.477^{* * *} \\
{[0.144]}\end{array}$ & $\begin{array}{c}-2.907^{* * *} \\
{[0.142]}\end{array}$ & $\begin{array}{c}-2.878 * * * \\
{[0.189]}\end{array}$ & $\begin{array}{c}-3.248^{* * *} \\
{[0.194]}\end{array}$ & $\begin{array}{c}-3.428^{* * *} \\
{[0.208]}\end{array}$ & $\begin{array}{c}-1.793^{* * *} \\
{[0.147]}\end{array}$ & $\begin{array}{c}-2.066^{* * *} \\
{[0.175]}\end{array}$ & $\begin{array}{c}3.283^{* * *} \\
{[0.175]}\end{array}$ \\
\hline Observ. & 2,040 & 2,068 & 1,960 & 2,043 & 2,040 & 2,068 & 1,960 & 2,043 & 2,040 & 2,068 & 1,960 & 2,043 \\
\hline R-squared & 0.005 & 0.039 & 0.051 & 0.022 & 0.022 & 0.069 & 0.069 & 0.041 & 0.146 & 0.096 & 0.070 & 0.121 \\
\hline
\end{tabular}

\begin{tabular}{|c|c|c|c|c|c|c|c|}
\hline & \multicolumn{3}{|c|}{ Land ownership rights } & \multirow{2}{*}{$\frac{\frac{\text { Land }}{\text { markets }}}{(16)}$} & \multicolumn{3}{|c|}{ Regulated access } \\
\hline & $\begin{array}{l}\text { Individual } \\
\text { (13) }\end{array}$ & $\begin{array}{c}\text { Family } \\
\text { (14) }\end{array}$ & $\begin{array}{c}\text { Communal } \\
\text { (15) }\end{array}$ & & $\begin{array}{c}\text { Pasture } \\
\text { (17) }\end{array}$ & $\begin{array}{c}\text { Forest } \\
\text { (18) }\end{array}$ & $\begin{array}{c}\text { Crop Land } \\
\text { (19) }\end{array}$ \\
\hline Inpopulation & $\begin{array}{c}0.114 \\
(0.062)\end{array}$ & $\begin{array}{c}-0.043^{* * *} \\
(0.011)\end{array}$ & $\begin{array}{c}0.008 \\
(0.007)\end{array}$ & $\begin{array}{c}0.019 * * * \\
(0.006)\end{array}$ & $\begin{array}{c}0.019 \\
(0.011)\end{array}$ & $\begin{array}{c}0.033 \\
(0.027)\end{array}$ & $\begin{array}{l}-0.030 \\
(0.021)\end{array}$ \\
\hline year $==1996$ & $\begin{array}{c}0.012 \\
(0.027)\end{array}$ & $\begin{array}{c}0.010 \\
(0.025)\end{array}$ & $\begin{array}{l}-0.003 \\
(0.016)\end{array}$ & $\begin{array}{c}0.007 \\
(0.013)\end{array}$ & $\begin{array}{c}0.030 \\
(0.020)\end{array}$ & $\begin{array}{c}0.089 * * \\
(0.037)\end{array}$ & $\begin{array}{l}-0.003 \\
(0.047)\end{array}$ \\
\hline year $==2006$ & $\begin{array}{c}0.037 \\
(0.027)\end{array}$ & $\begin{array}{c}-0.004 \\
(0.025)\end{array}$ & $\begin{array}{c}0.006 \\
(0.016)\end{array}$ & $\begin{array}{c}0.056^{* * *} \\
(0.014)\end{array}$ & $\begin{array}{c}0.085^{* * *} \\
(0.021)\end{array}$ & $\begin{array}{c}0.152^{* * *} \\
(0.038)\end{array}$ & $\begin{array}{c}0.031 \\
(0.047)\end{array}$ \\
\hline Constant & $\begin{array}{c}0.511^{* * *} \\
(0.083)\end{array}$ & $\begin{array}{c}0.973 * * * \\
(0.078)\end{array}$ & $\begin{array}{c}0.043 \\
(0.053)\end{array}$ & $\begin{array}{l}-0.077^{*} \\
(0.039)\end{array}$ & $\begin{array}{c}0.088 \\
(0.062)\end{array}$ & $\begin{array}{c}1.584 * * * \\
(0.119)\end{array}$ & $\begin{array}{c}2.765^{* * *} \\
(0.150)\end{array}$ \\
\hline Observations & 2,076 & 2,076 & 2,076 & 2,076 & 2,076 & 2,076 & 2,076 \\
\hline R-squared & 0.002 & 0.007 & 0.001 & 0.012 & 0.008 & 0.010 & 0.000 \\
\hline
\end{tabular}

Notes: Population and distance measures are in logs, with proximity defined as its additive inverse (- $\log [$ distance]), so that coefficients can be read as elasticities and a positive coefficient implies closer facilities. The regression also controls for 45 province dummies (not shown). Robust standard errors in brackets, and asterisks indicate significance levels at ${ }^{* * *} \mathrm{p}<0.01,{ }^{* *} \mathrm{p}<0.05,{ }^{*} \mathrm{p}<0.1$. 
Table 4: OLS regression results for public infrastructure and institutions on village-level population and diversity

\begin{tabular}{|c|c|c|c|c|c|c|c|c|c|c|c|c|}
\hline & \multicolumn{4}{|c|}{ Proximity of farthest source (km) } & \multicolumn{4}{|c|}{ Proximity to all sources (km) } & \multicolumn{4}{|c|}{ Proximity to closest source $(\mathrm{km})$} \\
\hline & $\begin{array}{c}\text { Services } \\
(1)\end{array}$ & $\begin{array}{c}\text { Infrastr. } \\
(2)\end{array}$ & $\begin{array}{c}\text { Religion } \\
(3)\end{array}$ & $\begin{array}{c}\text { Markets } \\
(4)\end{array}$ & $\begin{array}{c}\text { Services } \\
(5)\end{array}$ & $\begin{array}{c}\text { Infrastr. } \\
\text { (6) }\end{array}$ & $\begin{array}{c}\text { Religion } \\
(7) \\
\end{array}$ & $\begin{array}{c}\text { Markets } \\
(8)\end{array}$ & $\begin{array}{c}\text { Services } \\
(9)\end{array}$ & $\begin{array}{c}\text { Infrastr. } \\
\text { (10) }\end{array}$ & $\begin{array}{l}\text { Religion } \\
(11)\end{array}$ & $\begin{array}{c}\text { Markets } \\
(12)\end{array}$ \\
\hline \multirow{2}{*}{ Population } & $0.057^{* *}$ & 0.022 & $0.177^{* * *}$ & $0.183^{* * *}$ & $0.057^{* *}$ & $0.065^{* * *}$ & $0.176 * * *$ & $0.208^{* * *}$ & $0.097^{* * *}$ & $0.143^{* * *}$ & $0.169 * * *$ & $0.297^{* * *}$ \\
\hline & $(0.026)$ & $(0.027)$ & $(0.032)$ & $(0.035)$ & $(0.023)$ & $(0.022)$ & $(0.028)$ & $(0.029)$ & $(0.032)$ & $(0.021)$ & $(0.025)$ & $(0.025)$ \\
\hline \multirow{2}{*}{ \# of land chiefs } & -0.004 & $-0.018^{* *}$ & $0.016^{*}$ & $0.046^{* * *}$ & -0.004 & 0.002 & $0.016^{* *}$ & $0.043 * * *$ & 0.018 & $0.018^{* * *}$ & $0.020^{* * *}$ & $0.027 * * *$ \\
\hline & $(0.006)$ & $(0.007)$ & $(0.010)$ & $(0.010)$ & $(0.005)$ & $(0.008)$ & $(0.008)$ & $(0.008)$ & $(0.017)$ & $(0.007)$ & $(0.007)$ & $(0.008)$ \\
\hline \multirow{2}{*}{ \# of ethnic groups } & $0.024 * *$ & 0.015 & $0.048 * * *$ & 0.010 & $0.029 * * *$ & $0.029 * * *$ & $0.043^{* * *}$ & $0.020^{*}$ & $0.055^{* * *}$ & $0.026^{* * *}$ & $0.035^{* * *}$ & $0.040^{* * *}$ \\
\hline & $(0.011)$ & $(0.010)$ & $(0.010)$ & $(0.012)$ & $(0.010)$ & $(0.007)$ & $(0.009)$ & $(0.010)$ & $(0.010)$ & $(0.005)$ & $(0.006)$ & $(0.008)$ \\
\hline \multirow{2}{*}{ \# of clans } & 0.001 & -0.004 & $0.016^{* * *}$ & $0.018^{* * *}$ & 0.002 & -0.001 & $0.013^{* * *}$ & $0.016^{* * *}$ & $0.008^{* *}$ & $0.007 * * *$ & $0.005^{* * *}$ & $0.013^{* * *}$ \\
\hline & $(0.003)$ & $(0.003)$ & $(0.003)$ & $(0.004)$ & $(0.003)$ & $(0.002)$ & $(0.002)$ & $(0.003)$ & $(0.004)$ & $(0.002)$ & $(0.002)$ & $(0.002)$ \\
\hline \multirow{2}{*}{ year $==1996$} & -0.072 & $0.184^{* * *}$ & $0.139 *$ & -0.008 & 0.012 & $0.198 * * *$ & $0.171^{* * *}$ & 0.048 & $0.188^{* * *}$ & $0.285^{* * *}$ & $0.208^{* * *}$ & $0.189^{* * *}$ \\
\hline & $(0.057)$ & $(0.057)$ & $(0.073)$ & $(0.077)$ & $(0.051)$ & $(0.048)$ & $(0.063)$ & $(0.066)$ & $(0.060)$ & $(0.055)$ & $(0.059)$ & $(0.061)$ \\
\hline \multirow{2}{*}{ year $==2006$} & 0.027 & $0.516^{* * *}$ & $0.527 * * *$ & 0.070 & $0.250 * * *$ & $0.560^{* * *}$ & $0.536^{* * *}$ & $0.230 * * *$ & $1.061 * * *$ & $0.592^{* * *}$ & $0.477^{* * *}$ & $0.663^{* * *}$ \\
\hline & $(0.053)$ & $(0.057)$ & $(0.071)$ & $(0.076)$ & $(0.047)$ & $(0.047)$ & $(0.061)$ & $(0.064)$ & $(0.068)$ & $(0.048)$ & $(0.055)$ & $(0.057)$ \\
\hline \multirow{2}{*}{ Constant } & $-3.705^{* * *}$ & $-3.344 * * *$ & $-3.193^{* * *}$ & $-3.372^{* * *}$ & $-3.552^{* * *}$ & $-3.009 * * *$ & $-2.902 * * *$ & $-3.372^{* * *}$ & $-3.551 * * *$ & $-1.901 * * *$ & $-2.156^{* * *}$ & $-3.472 * * *$ \\
\hline & $(0.174)$ & $(0.185)$ & $(0.228)$ & $(0.236)$ & $(0.152)$ & $(0.150)$ & (0.197) & $(0.202)$ & $(0.217)$ & $(0.153)$ & $(0.185)$ & (0.179) \\
\hline Observations & 1,810 & 1,835 & 1,728 & 1,813 & 1,810 & 1,835 & 1,728 & 1,813 & 1,810 & 1,835 & 1,728 & 1,813 \\
\hline R-squared & 0.013 & 0.048 & 0.094 & 0.048 & 0.036 & 0.087 & 0.109 & 0.075 & 0.170 & 0.120 & 0.092 & 0.170 \\
\hline
\end{tabular}

Notes: Population and distance measures are in $\log$ s, with proximity defined as its additive inverse (- $\log [$ distance]), so that coefficients can be read as elasticities and a positive coefficient implies closer facilities. The regression also controls for 45 province dummies (not shown). Robust standard errors in brackets, and asterisks indicate significance levels at *** $\mathrm{p}<0.01,{ }^{* *} \mathrm{p}<0.05,{ }^{*} \mathrm{p}<0.1$. 
Table 4 (continued)

\begin{tabular}{|c|c|c|c|c|c|c|c|}
\hline & \multicolumn{3}{|c|}{ Land ownership rights } & \multirow{2}{*}{$\begin{array}{l}\text { Land } \\
\text { Markets } \\
\text { (16) }\end{array}$} & \multicolumn{3}{|c|}{ Regulated access } \\
\hline & $\begin{array}{c}\text { Individual } \\
\text { (13) }\end{array}$ & $\begin{array}{c}\text { Family } \\
\text { (14) }\end{array}$ & $\begin{array}{c}\text { Communal } \\
\text { (15) }\end{array}$ & & $\begin{array}{c}\text { Pasture } \\
\text { (17) }\end{array}$ & $\begin{array}{c}\text { Forest } \\
(18)\end{array}$ & $\begin{array}{c}\text { Crop Land } \\
\text { (19) }\end{array}$ \\
\hline \multirow[t]{2}{*}{ Population } & 0.020 & $-0.051^{* * *}$ & 0.003 & $0.020 * * *$ & 0.013 & $-0.046 * *$ & -0.033 \\
\hline & $(0.012)$ & $(0.012)$ & $(0.008)$ & $(0.006)$ & (0.009) & $(0.018)$ & $(0.023)$ \\
\hline \multirow[t]{2}{*}{ \# of land chiefs } & $0.011 * * *$ & $0.011 * * *$ & $-0.003^{*}$ & $-0.006 * *$ & 0.004 & $-0.022 * * *$ & 0.001 \\
\hline & $(0.004)$ & $(0.003)$ & $(0.002)$ & $(0.003)$ & $(0.005)$ & $(0.006)$ & $(0.006)$ \\
\hline \multirow[t]{2}{*}{ \# of ethnic groups } & 0.004 & $-0.011 * * *$ & $0.005^{*}$ & $0.013 * * *$ & $-0.008 * * *$ & $0.014^{* *}$ & -0.005 \\
\hline & $(0.004)$ & $(0.004)$ & $(0.003)$ & $(0.003)$ & $(0.003)$ & $(0.006)$ & $(0.007)$ \\
\hline \multirow[t]{2}{*}{ \# of clans } & $-0.007 * * *$ & $0.006 * * *$ & $0.003^{* * *}$ & $-0.004 * * *$ & -0.001 & $0.006 * * *$ & -0.001 \\
\hline & $(0.001)$ & $(0.001)$ & $(0.001)$ & (0.001) & $(0.001)$ & $(0.002)$ & $(0.002)$ \\
\hline \multirow[t]{2}{*}{ year $==1996$} & 0.018 & 0.011 & -0.003 & 0.006 & 0.030 & $0.091^{* *}$ & 0.002 \\
\hline & $(0.028)$ & $(0.026)$ & $(0.018)$ & $(0.014)$ & $(0.022)$ & (0.039) & (0.049) \\
\hline \multirow[t]{2}{*}{ year== 2006} & 0.042 & -0.009 & 0.005 & $0.052 * * *$ & $0.086 * * *$ & $0.153^{* * *}$ & 0.033 \\
\hline & $(0.028)$ & $(0.026)$ & $(0.018)$ & $(0.015)$ & $(0.023)$ & $(0.041)$ & $(0.049)$ \\
\hline \multirow[t]{2}{*}{ Constant } & $0.527^{* * *}$ & $1.001 * * *$ & 0.040 & $-0.077^{*}$ & 0.103 & $1.593 * * *$ & $2.823 * * *$ \\
\hline & $(0.088)$ & $(0.082)$ & $(0.058)$ & $(0.041)$ & $(0.066)$ & $(0.127)$ & $(0.158)$ \\
\hline Observations & 1,843 & 1,843 & 1,843 & 1,843 & 1,843 & 1,843 & 1,843 \\
\hline R-squared & 0.022 & 0.026 & 0.019 & 0.039 & 0.013 & 0.026 & 0.001 \\
\hline
\end{tabular}

Notes: The regression also controls for 45 province dummies (not shown). Robust standard errors in brackets, and asterisks indicate significance levels at $* * * \mathrm{p}<0.01, * * \mathrm{p}<0.05, * \mathrm{p}<0.1$. 
Table 5: First stage regression results for IV estimation

\begin{tabular}{|c|c|c|c|c|c|c|}
\hline VARIABLES & $\begin{array}{c}(1) \\
\text { All } \\
\text { provinces }\end{array}$ & $\begin{array}{c}(2) \\
\text { Non-Volta } \\
\text { regions }\end{array}$ & $\begin{array}{c}\text { (3) } \\
\text { Volta Valley } \\
\text { regions }\end{array}$ & $\begin{array}{c}(4) \\
\text { All } \\
\text { provinces }\end{array}$ & $\begin{array}{c}(5) \\
\text { Non-Volta } \\
\text { regions }\end{array}$ & $\begin{array}{c}\text { (6) } \\
\text { Volta Valley } \\
\text { regions }\end{array}$ \\
\hline \multicolumn{7}{|l|}{ log distance to } \\
\hline river & $\begin{array}{c}-0.247^{\star \star \star} \\
{[0.041]}\end{array}$ & $\begin{array}{c}-0.183^{\star \star \star} \\
{[0.057]}\end{array}$ & $\begin{array}{c}-0.312^{\star \star \star} \\
{[0.059]}\end{array}$ & & & \\
\hline year $==1996$ & $\begin{array}{l}-0.111 \\
{[0.244]}\end{array}$ & $\begin{array}{l}-0.324 \\
{[0.368]}\end{array}$ & $\begin{array}{c}0.030 \\
{[0.330]}\end{array}$ & $\begin{array}{c}-0.165 \\
{[0.231]}\end{array}$ & $\begin{array}{l}-0.297 \\
{[0.373]}\end{array}$ & $\begin{array}{l}-0.089 \\
{[0.293]}\end{array}$ \\
\hline year $==2006$ & $\begin{array}{c}-0.896^{\star * \star} \\
{[0.242]}\end{array}$ & $\begin{array}{l}-0.687^{\star} \\
{[0.369]}\end{array}$ & $\begin{array}{c}-1.107^{\star \star \star} \\
{[0.324]}\end{array}$ & $\begin{array}{c}-0.916^{\star * *} \\
{[0.255]}\end{array}$ & $\begin{array}{l}-0.733^{*} \\
{[0.411]}\end{array}$ & $\begin{array}{c}-1.109^{\star * *} \\
{[0.324]}\end{array}$ \\
\hline distanceX1996 & $\begin{array}{c}0.053 \\
{[0.060]}\end{array}$ & $\begin{array}{c}0.082 \\
{[0.088]}\end{array}$ & $\begin{array}{c}0.038 \\
{[0.084]}\end{array}$ & $\begin{array}{c}0.066 \\
{[0.057]}\end{array}$ & $\begin{array}{c}0.077 \\
{[0.089]}\end{array}$ & $\begin{array}{c}0.067 \\
{[0.075]}\end{array}$ \\
\hline distanceX2006 & $\begin{array}{l}0.174^{\star \star *} \\
{[0.060]}\end{array}$ & $\begin{array}{c}0.079 \\
{[0.089]}\end{array}$ & $\begin{array}{l}0.265^{\star * \star} \\
{[0.082]}\end{array}$ & $\begin{array}{l}0.179^{* * *} \\
{[0.063]}\end{array}$ & $\begin{array}{c}0.090 \\
{[0.099]}\end{array}$ & $\begin{array}{l}0.267^{\star \star \star} \\
{[0.082]}\end{array}$ \\
\hline Constant & $\begin{array}{c}7.942^{\star * *} \\
{[0.164]}\end{array}$ & $\begin{array}{c}7.885^{\star * *} \\
{[0.236]}\end{array}$ & $\begin{array}{c}8.023^{\star * *} \\
{[0.230]}\end{array}$ & $\begin{array}{c}6.975^{\star \star *} \\
{[0.029]}\end{array}$ & $\begin{array}{c}7.160^{\star * *} \\
{[0.038]}\end{array}$ & $\begin{array}{c}6.815^{\star * \star} \\
{[0.043]}\end{array}$ \\
\hline Observations & 2,076 & 959 & 1,117 & 2,076 & 959 & 1,117 \\
\hline R-squared & 0.189 & 0.143 & 0.217 & 0.489 & 0.452 & 0.513 \\
\hline F-Stat Inst & 19.20 & 10.82 & 11.79 & 12.44 & 10.67 & 6.602 \\
\hline
\end{tabular}


Table 6.1: IV regression results for infrastructure and institutions on predicted village population, with province fixed effects

\begin{tabular}{|c|c|c|c|c|c|c|c|c|c|c|c|c|}
\hline & \multicolumn{4}{|c|}{ Proximity of farthest source $(\mathrm{km})$} & \multicolumn{4}{|c|}{ Proximity to all sources (km) } & \multicolumn{4}{|c|}{ Proximity to closest source (km) } \\
\hline & $\begin{array}{c}\text { Services } \\
\text { (1) }\end{array}$ & $\begin{array}{l}\text { Infrastr. } \\
(2)\end{array}$ & $\begin{array}{c}\text { Religion } \\
(3)\end{array}$ & $\begin{array}{c}\text { Markets } \\
(4)\end{array}$ & $\begin{array}{c}\text { Services } \\
\text { (5) }\end{array}$ & $\begin{array}{c}\text { Infrastr. } \\
(6)\end{array}$ & $\begin{array}{c}\text { Religion } \\
(7)\end{array}$ & $\begin{array}{c}\text { Markets } \\
\text { (8) }\end{array}$ & $\begin{array}{c}\text { Services } \\
(9)\end{array}$ & $\begin{array}{l}\text { Infrastr. } \\
(10)\end{array}$ & $\begin{array}{c}\text { Religion } \\
(11)\end{array}$ & $\begin{array}{c}\text { Markets } \\
\text { (12) }\end{array}$ \\
\hline \multirow[t]{2}{*}{ Inpopulation } & $0.273^{*}$ & $0.320^{*}$ & $1.026^{* * *}$ & \multirow{2}{*}{$\begin{array}{c}0.665^{\star \star \star} \\
{[0.223]}\end{array}$} & \multirow{2}{*}{$\begin{array}{l}0.390^{* *} \\
{[0.152]}\end{array}$} & $0.696^{* * *}$ & $0.912^{* * *}$ & $0.735^{\star * *}$ & $0.973^{* * *}$ & $0.697^{* * *}$ & $0.594^{* * *}$ & $0.959^{* * *}$ \\
\hline & [0.163] & {$[0.172]$} & {$[0.194]$} & & & {$[0.160]$} & {$[0.167]$} & {$[0.197]$} & {$[0.219]$} & {$[0.160]$} & {$[0.143]$} & {$[0.182]$} \\
\hline year==1996 & $\begin{array}{l}-0.082 \\
{[0.056]}\end{array}$ & $\begin{array}{c}0.150^{* * *} \\
{[0.056]}\end{array}$ & $\begin{array}{c}0.059 \\
{[0.072]}\end{array}$ & $\begin{array}{l}-0.065 \\
{[0.070]}\end{array}$ & $\begin{array}{c}-0.013 \\
{[0.051]}\end{array}$ & $\begin{array}{l}0.135^{\star *} \\
{[0.053]}\end{array}$ & $\begin{array}{c}0.108^{*} \\
{[0.062]}\end{array}$ & $\begin{array}{l}-0.008 \\
{[0.062]}\end{array}$ & $\begin{array}{c}0.101 \\
{[0.070]}\end{array}$ & $\begin{array}{c}0.247^{* * *} \\
{[0.054]}\end{array}$ & $\begin{array}{c}0.190^{* * *} \\
{[0.055]}\end{array}$ & $\begin{array}{l}0.128^{* *} \\
{[0.062]}\end{array}$ \\
\hline year $==2006$ & $\begin{array}{c}0.083 \\
{[0.058]}\end{array}$ & $\begin{array}{c}0.556^{* * *} \\
{[0.064]}\end{array}$ & $\begin{array}{c}0.715^{\star * \star} \\
{[0.092]}\end{array}$ & $\begin{array}{l}0.184^{\star *} \\
{[0.085]}\end{array}$ & $\begin{array}{c}0.332^{* * *} \\
{[0.055]}\end{array}$ & $\begin{array}{c}0.681^{* * *} \\
{[0.062]}\end{array}$ & $\begin{array}{c}0.712^{* * *} \\
{[0.079]}\end{array}$ & $\begin{array}{c}0.350^{* * *} \\
{[0.076]}\end{array}$ & $\begin{array}{l}1.281^{* * *} \\
{[0.085]}\end{array}$ & $\begin{array}{c}0.719^{* * *} \\
{[0.065]}\end{array}$ & $\begin{array}{c}0.614^{* \star *} \\
{[0.066]}\end{array}$ & $\begin{array}{c}0.789^{\star * *} \\
{[0.077]}\end{array}$ \\
\hline Observations & 2,040 & 2,068 & 1,960 & 2,043 & 2,040 & 2,068 & 1,960 & 2,043 & 2,040 & 2,068 & 1,960 & 2,043 \\
\hline Number of prov & 45 & 45 & 45 & 45 & 45 & 45 & 45 & 45 & 45 & 45 & 45 & 45 \\
\hline Hansen J stat. & 2.067 & 8.224 & 5.624 & 0.0629 & 3.947 & 8.279 & 4.655 & 0.0820 & 7.047 & 2.193 & 1.064 & 1.062 \\
\hline \multirow[t]{3}{*}{ Prob HJS } & 0.356 & 0.0164 & 0.0601 & 0.969 & 0.139 & 0.0159 & 0.0975 & 0.960 & 0.0295 & 0.334 & 0.587 & 0.588 \\
\hline & \multicolumn{4}{|c|}{$\underline{\text { Land ownership rights }}$} & \multicolumn{4}{|c|}{ Regulated access } & & & & \\
\hline & $\begin{array}{c}\text { Individual } \\
\text { (13) }\end{array}$ & $\begin{array}{c}\text { Family } \\
(14)\end{array}$ & $\begin{array}{c}\text { Communal } \\
\text { (15) }\end{array}$ & $\frac{\mathrm{mar}}{(1}$ & 5) & $\begin{array}{c}\text { Pasture } \\
(17)\end{array}$ & $\begin{array}{c}\text { Forest } \\
(18)\end{array}$ & $\begin{array}{c}\text { Crop Land } \\
\text { (19) }\end{array}$ & & & & \\
\hline Inpopulation & $\begin{array}{l}0.119^{* *} \\
{[0.051]}\end{array}$ & $\begin{array}{c}-0.150^{\star *} \\
{[0.064]}\end{array}$ & $\begin{array}{c}0.074 \\
{[0.046]}\end{array}$ & $\begin{array}{l}0.0 \\
{[0.0}\end{array}$ & & $\begin{array}{l}0.224^{* * *} \\
{[0.071]}\end{array}$ & $\begin{array}{c}0.113 \\
{[0.106]}\end{array}$ & $\begin{array}{l}-0.078^{*} \\
{[0.341]}\end{array}$ & & & & \\
\hline year==1996 & $\begin{array}{c}0.006 \\
{[0.023]}\end{array}$ & $\begin{array}{c}0.019 \\
{[0.023]}\end{array}$ & $\begin{array}{l}-0.007 \\
{[0.016]}\end{array}$ & 0.0 & & $\begin{array}{c}0.013 \\
{[0.022]}\end{array}$ & $\begin{array}{l}0.073^{\star *} \\
{[0.035]}\end{array}$ & $\begin{array}{c}0.028 \\
{[0.043]}\end{array}$ & & & & \\
\hline year==2006 & $\begin{array}{l}0.066^{* *} \\
{[0.027]}\end{array}$ & $\begin{array}{l}-0.028 \\
{[0.026]}\end{array}$ & $\begin{array}{c}0.020 \\
{[0.018]}\end{array}$ & $\begin{array}{l}0.06 \\
{[0.6}\end{array}$ & & $\begin{array}{l}0.133^{* * *} \\
{[0.025]}\end{array}$ & $\begin{array}{c}0.185^{\star * *} \\
{[0.041]}\end{array}$ & $\begin{array}{c}-0.031 \\
{[0.048]}\end{array}$ & & & & \\
\hline Observations & 2,076 & 2,076 & 2,076 & 2,0 & & 2,076 & 2,076 & 2,076 & & & & \\
\hline Number of prov & 45 & 45 & 45 & & & 45 & 45 & 45 & & & & \\
\hline Hansen J stat. & 0.456 & 1.503 & 1.204 & 2.2 & & 3.042 & 1.008 & 0.965 & & & & \\
\hline Prob HJS & 0.796 & 0.472 & 0.548 & 0.3 & & 0.218 & 0.604 & 0.617 & & & & \\
\hline
\end{tabular}

Notes: First stage results are shown in Column 3 of Table 5. Population and proximity measures are in logs. All regressions control for 45 province dummies (not shown). Robust standard errors in brackets, and asterisks indicate significance levels at $* * * \mathrm{p}<0.01, * * \mathrm{p}<0.05, * \mathrm{p}<0.1$. 
Table 6.2: IV regression results for infrastructure and institutions on predicted village population, with village fixed effects Proximity of farthest source $(\mathrm{km})$

Proximity to all sources $(\mathrm{km})$

\begin{tabular}{|c|c|c|c|c|c|c|c|c|c|c|c|c|}
\hline & $\begin{array}{c}\text { Services } \\
(1)\end{array}$ & $\begin{array}{c}\text { Infrastr. } \\
(2)\end{array}$ & $\begin{array}{c}\text { Religion } \\
\text { (3) }\end{array}$ & $\begin{array}{c}\text { Markets } \\
\text { (4) }\end{array}$ & $\begin{array}{c}\text { Services } \\
\text { (5) }\end{array}$ & $\begin{array}{c}\text { Infrastr. } \\
(6)\end{array}$ & $\begin{array}{c}\text { Religion } \\
(7)\end{array}$ & $\begin{array}{c}\text { Markets } \\
\text { (8) }\end{array}$ & $\begin{array}{c}\text { Services } \\
\text { (9) }\end{array}$ & $\begin{array}{c}\text { Infrastr. } \\
(10)\end{array}$ & $\begin{array}{c}\text { Religion } \\
(11)\end{array}$ & $\begin{array}{c}\text { Markets } \\
(12)\end{array}$ \\
\hline \multirow[t]{2}{*}{ Inpopulation } & 0.106 & $0.777^{* *}$ & 0.103 & $0.701^{* *}$ & 0.300 & 0.387 & 0.025 & $0.564^{* *}$ & 0.491 & $0.980^{* *}$ & 0.191 & $0.556^{* * *}$ \\
\hline & [0.292] & [0.398] & [0.267] & [0.337] & [0.247] & [0.252] & [0.218] & [0.272] & [0.378] & [0.402] & {$[0.207]$} & [0.201] \\
\hline \multirow[t]{2}{*}{ year==1996 } & -0.035 & $0.273^{\star \star *}$ & $0.144^{\star * *}$ & -0.070 & $0.069^{*}$ & $0.252^{* * *}$ & $0.182^{* * *}$ & 0.005 & $0.264^{\star * *}$ & $0.237^{\star * *}$ & $0.240^{* * *}$ & $0.159^{* * *}$ \\
\hline & {$[0.045]$} & [0.063] & {$[0.044]$} & [0.053] & [0.039] & [0.039] & [0.036] & [0.043] & [0.057] & {$[0.061]$} & [0.035] & {$[0.046]$} \\
\hline \multirow[t]{2}{*}{ year==2006 } & -0.001 & $0.317^{\star * *}$ & $0.411^{* * *}$ & $0.196^{\star *}$ & $0.189^{* * *}$ & $0.446^{* * *}$ & $0.479^{* * *}$ & $0.316^{\star * *}$ & $0.984^{\star * *}$ & $0.794^{* * *}$ & $0.525^{\star * *}$ & $0.712^{\star \star \star}$ \\
\hline & {$[0.061]$} & [0.094] & {$[0.079]$} & {$[0.084]$} & [0.055] & {$[0.057]$} & [0.065] & [0.067] & [0.089] & [0.107] & {$[0.066]$} & {$[0.080]$} \\
\hline Observations & 2,027 & 2,066 & 1,936 & 2,033 & 2,027 & 2,066 & 1,936 & 2,033 & 2,027 & 2,066 & 1,936 & 2,033 \\
\hline Number of vfe & 692 & 704 & 670 & 694 & 692 & 704 & 670 & 694 & 692 & 704 & 670 & 694 \\
\hline Hansen J stat. & 1.524 & 0.00170 & 0.0243 & 0.00699 & 0.920 & 0.0217 & 0.0223 & 0.0152 & 0.0416 & 0.766 & 0.0732 & 0.0348 \\
\hline \multirow[t]{3}{*}{ Prob HJS } & 0.217 & 0.967 & 0.876 & 0.933 & 0.337 & 0.883 & 0.881 & 0.902 & 0.838 & 0.382 & 0.787 & 0.852 \\
\hline & \multicolumn{3}{|c|}{ Land ownership rights } & \multicolumn{2}{|c|}{$\underline{\text { Land }}$} & \multicolumn{3}{|c|}{$\underline{\text { Regulated access }}$} & & & & \\
\hline & $\begin{array}{c}\text { Individual } \\
\text { (13) }\end{array}$ & $\begin{array}{r}\text { Fam } \\
(14\end{array}$ & Com & $\begin{array}{l}\text { nunal } \\
5)\end{array}$ & $\frac{\text { markets }}{(16)}$ & $\begin{array}{c}\text { Pasture } \\
\text { (17) }\end{array}$ & $\begin{array}{c}\text { Forest } \\
(18)\end{array}$ & $\begin{array}{c}\text { Crop Land } \\
\text { (19) }\end{array}$ & & & & \\
\hline \multirow[t]{2}{*}{ Inpopulation } & $0.053^{* *}$ & 0.00 & & $23^{*}$ & $0.044^{* *}$ & -0.034 & -0.125 & -0.034 & & & & \\
\hline & {$[0.025]$} & {$[0.02$} & & $14]$ & {$[0.022]$} & {$[0.067]$} & [0.130] & {$[0.072]$} & & & & \\
\hline \multirow[t]{2}{*}{ year==1996 } & $0.015^{\star *}$ & 0.00 & & 03 & 0.012 & $0.033^{\star * *}$ & $0.101^{* \star *}$ & 0.013 & & & & \\
\hline & {$[0.007]$} & {$[0.00$} & & 03] & {$[0.008]$} & {$[0.010]$} & {$[0.020]$} & [0.012] & & & & \\
\hline \multirow[t]{2}{*}{ year==2006 } & $0.052^{* * *}$ & 0.00 & & 01 & $.041^{* * *}$ & $0.075^{\star * *}$ & $0.136^{* * *}$ & 0.023 & & & & \\
\hline & [0.015] & {$[0.00$} & & $02]$ & {$[0.013]$} & {$[0.017]$} & {$[0.031]$} & {$[0.016]$} & & & & \\
\hline Observations & 2,076 & 2,07 & & 76 & 2,076 & 2,076 & 2,076 & 2,076 & & & & \\
\hline Number of vfe & 705 & 70 & & 05 & 705 & 705 & 705 & 705 & & & & \\
\hline Hansen J stat. & 1.793 & 0.02 & & 210 & 0.0298 & 0.596 & 0.00628 & 0.786 & & & & \\
\hline Prob HJS & 0.181 & 0.88 & & 347 & 0.863 & 0.440 & 0.937 & 0.375 & & & & \\
\hline
\end{tabular}

Notes: First stage results are shown in Column 1 of Table 5. Population and proximity measures are in logs. All regressions control for village fixed effects. Robust standard errors in brackets, and asterisks indicate significance levels at ${ }^{* * *} \mathrm{p}<0.01,{ }^{* *} \mathrm{p}<0.05,{ }^{*} \mathrm{p}<0.1$. 
Table 6.3: IV regression results for infrastructure and institutions on village population, with province fixed effects, in Volta Valley only

Proximity of farthest source $(\mathrm{km})$

Proximity to all sources $(\mathrm{km})$

Services Infrastr. Religion Markets Services Infrastr. Religion Markets Services Infrastr. Religion Markets

\begin{tabular}{|c|c|c|c|c|c|c|c|c|c|c|c|c|}
\hline & (1) & $(2)$ & (3) & (4) & $(5)$ & (6) & (7) & (8) & (9) & $(10)$ & $(11)$ & $(12)$ \\
\hline \multirow[t]{2}{*}{ Inpopulation } & $0.406^{* *}$ & $0.396^{* *}$ & $0.653^{* * *}$ & $0.667^{* * *}$ & $0.478^{* * *}$ & $0.704^{* * *}$ & $0.633^{* * *}$ & $0.759^{* * *}$ & $0.979^{* * *}$ & $0.816^{* * *}$ & $0.532^{* * *}$ & $1.167^{\star * *}$ \\
\hline & [0.181] & {$[0.196]$} & [0.193] & {$[0.247]$} & [0.166] & [0.171] & [0.169] & [0.220] & [0.229] & [0.160] & {$[0.161]$} & [0.209] \\
\hline \multirow[t]{2}{*}{ year $==1996$} & $-0.143^{*}$ & $0.165^{*}$ & 0.058 & -0.113 & -0.071 & 0.109 & 0.123 & -0.054 & 0.029 & $0.158^{\star *}$ & $0.234^{\star * *}$ & 0.054 \\
\hline & [0.083] & [0.086] & [0.098] & [0.104] & {$[0.077]$} & {$[0.079]$} & [0.086] & [0.094] & {$[0.104]$} & {$[0.078]$} & {$[0.081]$} & {$[0.100]$} \\
\hline \multirow[t]{2}{*}{ year==2006 } & 0.073 & $0.574^{\star \star \star}$ & $0.613^{* \star *}$ & 0.137 & $0.303^{* \star *}$ & $0.619^{\star \star \star}$ & $0.656^{\star * *}$ & $0.305^{\star \star \star}$ & $1.172^{\star \star \star}$ & $0.560^{\star * *}$ & $0.634^{* * *}$ & $0.737^{\star * \star}$ \\
\hline & {$[0.074]$} & [0.082] & [0.102] & [0.097] & [0.069] & {$[0.078]$} & [0.089] & [0.089] & {$[0.106]$} & {$[0.077]$} & {$[0.077]$} & {$[0.101]$} \\
\hline Observations & 1,103 & 1,114 & 1,044 & 1,107 & 1,103 & 1,114 & 1,044 & 1,107 & 1,103 & 1,114 & 1,044 & 1,107 \\
\hline Number of prov & 23 & 23 & 23 & 23 & 23 & ,23 & 23 & 23 & 23 & 23 & 23 & 23 \\
\hline Hansen J stat. & 2.734 & 9.640 & 10.30 & 1.568 & 5.298 & 10.49 & 10.03 & 2.028 & 5.429 & 1.923 & 4.974 & 1.330 \\
\hline \multirow[t]{3}{*}{ Prob HJS } & 0.255 & 0.00807 & 0.00579 & 0.457 & 0.0707 & 0.00527 & 0.00665 & 0.363 & 0.0662 & 0.382 & 0.0832 & 0.514 \\
\hline & \multicolumn{4}{|c|}{ Land ownership rights } & Land & \multicolumn{3}{|c|}{$\underline{\text { Regulated access }}$} & & & & \\
\hline & $\begin{array}{l}\text { Individual } \\
\text { (13) }\end{array}$ & $\begin{array}{l}\text { Family } \\
\text { (14) }\end{array}$ & $\begin{array}{c}\text { Communal } \\
\text { (15) }\end{array}$ & & $\frac{\text { kets }}{6)}$ & $\begin{array}{l}\text { Pasture } \\
\text { (17) }\end{array}$ & $\begin{array}{c}\text { Forest } \\
\text { (18) }\end{array}$ & $\begin{array}{c}\text { Crop Land } \\
\text { (19) }\end{array}$ & & & & \\
\hline Inpopulation & $\begin{array}{l}0.226^{* \star *} \\
{[0.080]}\end{array}$ & $\begin{array}{l}-0.044 \\
{[0.064]}\end{array}$ & $\begin{array}{c}0.053 \\
{[0.053]}\end{array}$ & $\begin{array}{l}0.0 \\
{[0 .}\end{array}$ & $\begin{array}{l}6^{* \star \star} \\
12]\end{array}$ & $\begin{array}{c}0.233^{\star \star *} \\
{[0.069]}\end{array}$ & $\begin{array}{c}0.073 \\
{[0.121]}\end{array}$ & $\begin{array}{c}-0.080 \\
{[0.104]}\end{array}$ & & & & \\
\hline year $==1996$ & $\begin{array}{l}-0.016 \\
{[0.035]}\end{array}$ & $\begin{array}{c}0.014 \\
{[0.031]}\end{array}$ & $\begin{array}{l}-0.014 \\
{[0.025]}\end{array}$ & & 05 & $\begin{array}{c}0.005 \\
{[0.032]}\end{array}$ & $\begin{array}{l}0.092^{*} \\
{[0.052]}\end{array}$ & $\begin{array}{l}0.035 \\
{[0.055]}\end{array}$ & & & & \\
\hline year==2006 & $\begin{array}{l}0.076^{\star *} \\
{[0.034]}\end{array}$ & $\begin{array}{c}0.003 \\
{[0.029]}\end{array}$ & $\begin{array}{c}0.007 \\
{[0.023]}\end{array}$ & $\begin{array}{l}0.0 \\
{[0 .}\end{array}$ & $\begin{array}{l}3^{* * *} \\
14]\end{array}$ & $\begin{array}{l}0.119^{* * *} \\
{[0.030]}\end{array}$ & $\begin{array}{l}0.192^{* * *} \\
{[0.050]}\end{array}$ & $\begin{array}{c}0.060 \\
{[0.053]}\end{array}$ & & & & \\
\hline Observations & 1,117 & 1,117 & 1,117 & & 17 & 1,117 & 1,117 & 1,117 & & & & \\
\hline Number of prov & 23 & 23 & 23 & & 3 & 23 & 23 & 23 & & & & \\
\hline Hansen J stat. & 2.158 & 0.307 & 0.906 & & 42 & 4.172 & 0.825 & 0.0377 & & & & \\
\hline Prob HJS & 0.340 & 0.858 & 0.636 & & 63 & 0.124 & 0.662 & 0.981 & & & & \\
\hline
\end{tabular}

Notes: First stage results are shown in Column 2 of Table 5. Population and proximity measures are in logs. All regressions control for 45 province dummies (not shown). Robust standard errors in brackets, and asterisks indicate significance levels at $* * * \mathrm{p}<0.01, * * \mathrm{p}<0.05, * \mathrm{p}<0.1$. 
Table 6.4: IV regression results for infrastructure and institutions on village population, with village fixed effects, in Volta Valley only

Proximity of farthest source $(\mathrm{km})$

Proximity to all sources $(\mathrm{km})$

Proximity to closest source $(\mathrm{km})$

\begin{tabular}{|c|c|c|c|c|c|c|c|c|c|c|c|c|}
\hline & $\begin{array}{c}\text { Services } \\
\text { (1) }\end{array}$ & $\begin{array}{c}\text { Infrastr. } \\
\text { (2) }\end{array}$ & $\begin{array}{c}\text { Religion } \\
\text { (3) }\end{array}$ & $\begin{array}{l}\text { Markets } \\
\text { (4) }\end{array}$ & $\begin{array}{c}\text { Services } \\
\text { (5) }\end{array}$ & $\begin{array}{c}\text { Infrastr. } \\
(6)\end{array}$ & $\begin{array}{c}\text { Religion } \\
(7)\end{array}$ & $\begin{array}{c}\text { Markets } \\
\text { (8) }\end{array}$ & $\begin{array}{c}\text { Services } \\
\text { (9) }\end{array}$ & $\begin{array}{c}\text { Infrastr. } \\
(10)\end{array}$ & $\begin{array}{l}\text { Religion } \\
\text { (11) }\end{array}$ & $\begin{array}{l}\text { Markets } \\
(12)\end{array}$ \\
\hline \multirow[t]{2}{*}{ Inpopulation } & -0.171 & $0.629^{\star \star}$ & -0.337 & 0.197 & -0.292 & -0.294 & -0.174 & 0.268 & 0.004 & $0.741^{* * *}$ & 0.055 & $0.753^{* \star}$ \\
\hline & {$[0.267]$} & {$[0.312]$} & {$[0.278]$} & [0.208] & {$[0.217]$} & {$[0.198]$} & [0.225] & {$[0.187]$} & {$[0.278]$} & [0.272] & {$[0.203]$} & [0.302] \\
\hline \multirow{2}{*}{ year==1996 } & -0.048 & $0.352^{\star * \star}$ & $0.181^{* *}$ & -0.037 & 0.060 & $0.289^{* * *}$ & $0.226^{\star * *}$ & 0.024 & $0.206^{\star * *}$ & $0.181^{\star * *}$ & $0.308^{\star * *}$ & $0.127^{*}$ \\
\hline & {$[0.067]$} & [0.087] & {$[0.073]$} & [0.057] & {$[0.055]$} & {$[0.054]$} & [0.059] & {$[0.051]$} & [0.069] & [0.069] & [0.055] & {$[0.076]$} \\
\hline \multirow[t]{2}{*}{ year==2006 } & 0.019 & $0.490^{* * *}$ & $0.433^{\star * *}$ & $0.094^{\star \star}$ & $0.238^{* * *}$ & $0.537^{* * *}$ & $0.516^{* * *}$ & $0.262^{\star \star \star *}$ & $1.098^{\star * *}$ & $0.553^{* \star *}$ & $0.569^{* \star *}$ & $0.711^{* * *}$ \\
\hline & [0.052] & [0.068] & [0.077] & [0.045] & [0.047] & {$[0.040]$} & [0.064] & {$[0.040]$} & [0.065] & [0.073] & {$[0.060]$} & [0.076] \\
\hline Observations & 1,096 & 1,113 & 1,032 & 1,102 & 1,096 & 1,113 & 1,032 & 1,102 & 1,096 & 1,113 & 1,032 & 1,102 \\
\hline Number of vfe & 374 & 380 & 358 & 376 & 374 & 380 & 358 & 376 & 374 & 380 & 358 & 376 \\
\hline Hansen J stat. & 0.753 & 0.508 & 0.000555 & 1.304 & 0.258 & 1.105 & 0.0108 & 1.473 & 0.706 & 1.515 & 0.303 & 0.123 \\
\hline \multirow[t]{3}{*}{ Prob HJS } & 0.386 & 0.476 & 0.981 & 0.253 & 0.612 & 0.293 & 0.917 & 0.225 & 0.401 & 0.218 & 0.582 & 0.725 \\
\hline & \multicolumn{3}{|c|}{ Land ownership rights } & \multicolumn{5}{|c|}{$\underline{\text { Regulated access }}$} & & & & \\
\hline & $\begin{array}{l}\text { Individual } \\
\text { (13) }\end{array}$ & $\begin{array}{l}\text { Family } \\
\text { (14) }\end{array}$ & $\begin{array}{c}\text { Communal } \\
\text { (15) }\end{array}$ & $\frac{\mathrm{ma}}{1}$ & & $\begin{array}{l}\text { Pasture } \\
\text { (17) }\end{array}$ & $\begin{array}{l}\text { Forest } \\
\text { (18) }\end{array}$ & $\begin{array}{l}\text { Crop Land } \\
\text { (19) }\end{array}$ & & & & \\
\hline \multirow[t]{2}{*}{ Inpopulation } & $0.048^{\star *}$ & 0.005 & -0.013 & 0.0 & & 0.012 & -0.097 & -0.058 & & & & \\
\hline & {$[0.026]$} & {$[0.021]$} & {$[0.009]$} & {$[0$.} & & [0.059] & {$[0.120]$} & {$[0.084]$} & & & & \\
\hline \multirow[t]{2}{*}{ year $==1996$} & 0.018 & 0.007 & 0.002 & & & $.040^{* * *}$ & $0.122^{* * *}$ & 0.031 & & & & \\
\hline & [0.013] & {$[0.005]$} & {$[0.003]$} & {$[0 .($} & & {$[0.015]$} & {$[0.031]$} & [0.022] & & & & \\
\hline \multirow[t]{2}{*}{ year $==2006$} & $0.062^{* * *}$ & $0.008^{*}$ & 0.004 & 0.0 & & $.100^{* * *}$ & $0.180^{* * *}$ & $0.060^{* * *}$ & & & & \\
\hline & {$[0.013]$} & {$[0.005]$} & {$[0.003]$} & {$[0 .($} & & {$[0.015]$} & {$[0.027]$} & {$[0.020]$} & & & & \\
\hline Observations & 1,116 & 1,116 & 1,116 & 1 , & & 1,116 & 1,116 & 1,116 & & & & \\
\hline Number of vfe & 380 & 380 & 380 & & & 380 & 380 & 380 & & & & \\
\hline Hansen J stat. & 1.209 & 0.0574 & 0.333 & & & 2.118 & 0.0483 & 0.648 & & & & \\
\hline Prob HJS & 0.271 & 0.811 & 0.564 & & & 0.146 & 0.826 & 0.421 & & & & \\
\hline
\end{tabular}

Notes: First stage results for this regression are not shown. Population and proximity measures are in logs. All results control for village fixed effects. Robust standard errors in brackets, and asterisks indicate significance levels at $* * * \mathrm{p}<0.01, * * \mathrm{p}<0.05,{ }^{*} \mathrm{p}<0.1$. 
Table 6.5: IV regression results for infrastructure and institutions on village population, with province fixed effects, outside Volta Valley (Placebo regression)

\begin{tabular}{|c|c|c|c|c|c|c|c|c|c|c|c|c|}
\hline & \multicolumn{4}{|c|}{ Proximity of farthest source $(\mathrm{km})$} & \multicolumn{4}{|c|}{ Proximity to all sources $(\mathrm{km})$} & \multicolumn{4}{|c|}{ Proximity to closest source $(\mathrm{km})$} \\
\hline & $\begin{array}{l}\text { Services } \\
\text { (1) }\end{array}$ & $\begin{array}{l}\text { Infrastr. } \\
\text { (2) }\end{array}$ & $\begin{array}{c}\text { Religion } \\
\text { (3) }\end{array}$ & $\begin{array}{c}\text { Markets } \\
\text { (4) }\end{array}$ & $\begin{array}{c}\text { Services } \\
\text { (5) }\end{array}$ & $\begin{array}{l}\text { Infrastr. } \\
\text { (6) }\end{array}$ & $\begin{array}{l}\text { Religion } \\
\text { (7) }\end{array}$ & $\begin{array}{c}\text { Markets } \\
\text { (8) }\end{array}$ & $\begin{array}{l}\text { Services } \\
\text { (9) }\end{array}$ & $\begin{array}{l}\text { Infrastr. } \\
\text { (10) }\end{array}$ & $\begin{array}{c}\text { Religion } \\
\text { (11) }\end{array}$ & $\begin{array}{c}\text { Markets } \\
\text { (12) }\end{array}$ \\
\hline Inpopulation & $\begin{array}{l}-0.085 \\
{[0.307]}\end{array}$ & $\begin{array}{c}0.136 \\
{[0.316]}\end{array}$ & $\begin{array}{l}1.600^{* * *} \\
{[0.474]}\end{array}$ & $\begin{array}{c}0.317 \\
{[0.430]}\end{array}$ & $\begin{array}{c}0.123 \\
{[0.281]}\end{array}$ & $\begin{array}{l}0.609^{*} \\
{[0.317]}\end{array}$ & $\begin{array}{l}1.312^{* * *} \\
{[0.389]}\end{array}$ & $\begin{array}{c}0.413 \\
{[0.366]}\end{array}$ & $\begin{array}{l}0.996^{* *} \\
{[0.473]}\end{array}$ & $\begin{array}{c}0.313 \\
{[0.336]}\end{array}$ & $\begin{array}{l}0.576^{* *} \\
{[0.265]}\end{array}$ & $\begin{array}{c}0.413 \\
{[0.322]}\end{array}$ \\
\hline year $==1996$ & $\begin{array}{l}-0.039 \\
{[0.073]}\end{array}$ & $\begin{array}{c}0.114 \\
{[0.071]}\end{array}$ & $\begin{array}{c}0.119 \\
{[0.116]}\end{array}$ & $\begin{array}{l}-0.015 \\
{[0.092]}\end{array}$ & $\begin{array}{c}0.038 \\
{[0.065]}\end{array}$ & $\begin{array}{l}0.162^{* *} \\
{[0.065]}\end{array}$ & $\begin{array}{c}0.135 \\
{[0.095]}\end{array}$ & $\begin{array}{c}0.037 \\
{[0.079]}\end{array}$ & $\begin{array}{l}0.186^{* *} \\
{[0.094]}\end{array}$ & $\begin{array}{c}0.323^{* * *} \\
{[0.073]}\end{array}$ & $\begin{array}{l}0.149^{* *} \\
{[0.072]}\end{array}$ & $\begin{array}{l}0.165^{\star \star} \\
{[0.076]}\end{array}$ \\
\hline year $==2006$ & $\begin{array}{l}-0.025 \\
{[0.129]}\end{array}$ & $\begin{array}{c}0.472^{* * *} \\
{[0.141]}\end{array}$ & $\begin{array}{c}0.984^{\star \star *} \\
{[0.224]}\end{array}$ & $\begin{array}{c}0.098 \\
{[0.199]}\end{array}$ & $\begin{array}{l}0.275^{\star *} \\
{[0.118]}\end{array}$ & $\begin{array}{c}0.720^{\star * *} \\
{[0.139]}\end{array}$ & $\begin{array}{c}0.879^{* * *} \\
{[0.186]}\end{array}$ & $\begin{array}{c}0.273 \\
{[0.169]}\end{array}$ & $\begin{array}{l}1.421^{* * *} \\
{[0.199]}\end{array}$ & $\begin{array}{c}0.770^{* * *} \\
{[0.149]}\end{array}$ & $\begin{array}{c}0.574^{* * *} \\
{[0.131]}\end{array}$ & $\begin{array}{c}0.652^{\star * *} \\
{[0.148]}\end{array}$ \\
\hline Obse & 937 & & & 936 & 937 & & & 936 & 937 & & & 936 \\
\hline Numb & 22 & 22 & 2 & 22 & 22 & 22 & 22 & 22 & 22 & 22 & 22 & 22 \\
\hline Hansen J stat. & 1.285 & 1.696 & 0.379 & 2.857 & 1.093 & 0.882 & 0.444 & 1.538 & 2.559 & 1.703 & 0.810 & 1.014 \\
\hline Prob HJS & 0.526 & 0.428 & 0.827 & 0.240 & 0.579 & 0.643 & 0.801 & 0.463 & 0.278 & 0.427 & 0.667 & 0.602 \\
\hline
\end{tabular}

Notes: First stage results for this regression are not shown. Population and proximity measures are in logs. All regressions control for 45 province dummies (not shown). Robust standard errors in brackets, and asterisks indicate significance levels at $* * * p<0.01, * *$ 
Table 6.6: IV regression results for infrastructure and institutions on village population, with village fixed effects, outside Volta Valley (Placebo regression)

\begin{tabular}{|c|c|c|c|c|c|c|c|c|c|c|c|c|}
\hline & \multicolumn{4}{|c|}{ Proximity of farthest source $(\mathrm{km})$} & \multicolumn{4}{|c|}{ Proximity to all sources (km) } & \multicolumn{4}{|c|}{ Proximity to closest source $(\mathrm{km})$} \\
\hline & $\begin{array}{l}\text { Services } \\
\text { (1) }\end{array}$ & $\begin{array}{l}\text { Infrastr. } \\
\text { (2) }\end{array}$ & $\begin{array}{l}\text { Religion } \\
\text { (3) }\end{array}$ & $\begin{array}{l}\text { Markets } \\
\text { (4) }\end{array}$ & $\begin{array}{c}\text { Services } \\
\text { (5) }\end{array}$ & $\begin{array}{c}\text { Infrastr. } \\
(6)\end{array}$ & $\begin{array}{c}\text { Religion } \\
\text { (7) }\end{array}$ & $\begin{array}{c}\text { Markets } \\
\text { (8) }\end{array}$ & $\begin{array}{l}\text { Services } \\
\text { (9) }\end{array}$ & $\begin{array}{c}\text { Infrastr. } \\
\text { (10) }\end{array}$ & $\begin{array}{c}\text { Religion } \\
\text { (11) }\end{array}$ & $\begin{array}{c}\text { Markets } \\
\text { (12) }\end{array}$ \\
\hline \multirow[t]{2}{*}{ Inpopulation } & 0.443 & -0.405 & 0.739 & 1.341 & 0.007 & -0.146 & 0.753 & 0.779 & -2.033 & 1.375 & 0.695 & -0.298 \\
\hline & [1.059] & {$[0.963]$} & {$[1.018]$} & {$[1.281]$} & {$[0.741]$} & {$[0.670]$} & {$[0.931]$} & {$[0.806]$} & [2.518] & [1.522] & {$[0.867]$} & {$[0.661]$} \\
\hline \multirow[t]{2}{*}{ year $==1996$} & -0.014 & $0.152^{\star \star \star}$ & $0.135^{\star *}$ & -0.017 & $0.073^{*}$ & $0.192^{\star \star \star *}$ & $0.160^{\star * \star}$ & 0.037 & $0.254^{*}$ & $0.350^{* * *}$ & $0.183^{* * *}$ & $0.169^{\star \star *}$ \\
\hline & {$[0.055]$} & {$[0.057]$} & {$[0.066]$} & [0.089] & [0.039] & [0.038] & {$[0.058]$} & {$[0.056]$} & {$[0.137]$} & {$[0.091]$} & {$[0.057]$} & {$[0.046]$} \\
\hline \multirow[t]{2}{*}{ year==2006 } & 0.173 & 0.272 & $0.669^{*}$ & 0.520 & 0.244 & $0.442^{*}$ & $0.684^{\star}$ & 0.437 & 0.323 & $1.211^{* *}$ & $0.646^{\star}$ & 0.397 \\
\hline & [0.379] & [0.364] & [0.388] & [0.494] & [0.264] & [0.253] & [0.353] & [0.311] & [0.897] & [0.587] & [0.330] & {$[0.261]$} \\
\hline Observations & 931 & 953 & 904 & 931 & 931 & 953 & 904 & 931 & 931 & 953 & 904 & 931 \\
\hline Number of vfe & 318 & 324 & 312 & 318 & 318 & 324 & 312 & 318 & 318 & 324 & 312 & 318 \\
\hline Hansen J stat. & 0.231 & 1.142 & 0.375 & 1.551 & 0.698 & 1.144 & 0.366 & 1.814 & 0.319 & 0.00481 & 0.148 & 0.0415 \\
\hline \multirow[t]{3}{*}{ Prob HJS } & 0.631 & 0.285 & 0.540 & 0.213 & 0.403 & 0.285 & 0.545 & 0.178 & 0.572 & 0.945 & 0.701 & 0.839 \\
\hline & \multicolumn{3}{|c|}{ Land ownership rights } & \multicolumn{2}{|c|}{ Land } & \multicolumn{3}{|c|}{ Regulated access } & & & & \\
\hline & $\begin{array}{c}\text { Individual } \\
\text { (13) }\end{array}$ & $\begin{array}{c}\text { Family } \\
\text { (14) }\end{array}$ & $\begin{array}{c}\text { Communal } \\
\text { (15) }\end{array}$ & & & $\begin{array}{c}\text { Pasture } \\
\text { (17) }\end{array}$ & $\begin{array}{c}\text { Forest } \\
\text { (18) }\end{array}$ & $\begin{array}{c}\text { Crop Land } \\
\text { (19) }\end{array}$ & & & & \\
\hline Inpopulation & $\begin{array}{c}0.098 \\
{[0.136]}\end{array}$ & $\begin{array}{c}0.002 \\
{[0.003]}\end{array}$ & $\begin{array}{c}-0.047 \\
{[0.055]}\end{array}$ & & & $\begin{array}{l}-0.187 \\
{[0.247]}\end{array}$ & $\begin{array}{c}-0.108 \\
{[0.308]}\end{array}$ & $\begin{array}{c}0.087 \\
{[0.104]}\end{array}$ & & & & \\
\hline year $==1996$ & $\begin{array}{c}0.012 \\
{[0.008]}\end{array}$ & $\begin{array}{l}-0.000 \\
{[0.002]}\end{array}$ & $\begin{array}{c}0.002 \\
{[0.004]}\end{array}$ & & & $\begin{array}{l}0.017 \\
{[0.015]}\end{array}$ & $\begin{array}{c}0.072^{* * *} \\
{[0.020]}\end{array}$ & $\begin{array}{l}-0.004 \\
{[0.006]}\end{array}$ & & & & \\
\hline year $==2006$ & $\begin{array}{c}0.056 \\
{[0.053]}\end{array}$ & $\begin{array}{c}0.004 \\
{[0.004]}\end{array}$ & $\begin{array}{l}-0.011 \\
{[0.019]}\end{array}$ & & & $\begin{array}{l}-0.009 \\
{[0.091]}\end{array}$ & $\begin{array}{c}0.093 \\
{[0.115]}\end{array}$ & $\begin{array}{c}0.024 \\
{[0.036]}\end{array}$ & & & & \\
\hline Observations & 959 & 959 & 959 & & & 959 & 959 & 959 & & & & \\
\hline Number of vfe & 325 & 325 & 325 & & & 325 & 325 & 325 & & & & \\
\hline Hansen J stat. & 0.189 & 0.414 & 0.237 & & & 0.0564 & 0.0991 & 0.192 & & & & \\
\hline Prob HJS & 0.664 & 0.520 & 0.626 & & & 0.812 & 0.753 & 0.661 & & & & \\
\hline
\end{tabular}

Notes: First stage results for this regression are not shown. Population and proximity measures are in logs. All results control for village fixed effects. Robust standard errors in brackets, and asterisks indicate significance levels at $* * * \mathrm{p}<0.01,{ }^{* *} \mathrm{p}<0.05, * \mathrm{p}<0.1$. 
BURKINA FASO

Ministère de l'Agriculture de l'Hydraulique et des Ressources Halieutiques

DIRECTION GENERALE DE LA PROMOTION DE L'ECONOMIE RURALE

Direction de la Prospective et des Statistiques Agricoles et Alimentaires

\section{ENQUETE COMMUNAUTAIRE}

\begin{tabular}{|c|l|c|c|}
\hline $\mathbf{N o}$ & Eléments d'identification & Nom & Code \\
\hline $\mathbf{1}$ & Région & & \\
\hline $\mathbf{2}$ & Province & \\
\hline $\mathbf{3}$ & $\begin{array}{l}\text { Commune } \\
\mathbf{4}\end{array}$ & $\begin{array}{l}\text { lype de localité } \\
1=\text { urbain } \\
2=\text { rural }\end{array}$ & \\
\hline $\mathbf{5}$ & Village / secteur & & \\
\hline $\mathbf{6}$ & Latitude & \\
\hline $\mathbf{7}$ & Longitude & \\
\hline
\end{tabular}

Nom du contrôleur :

L_C_____ $\mid$

Date de l'interview :
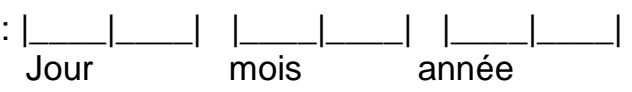

Nom et visa du superviseur :

Date de contrôle :

: I Jour
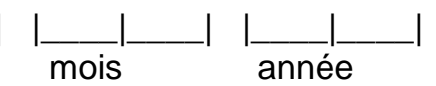

Résultat du contrôle

( 1 = aucun problème $; 2$ = questionnaire corrigé $; 3=$ questionnaire repris)

Nom et prénom(s) de l'agent de saisie $A$ :

Nom et prénom(s) de l'agent de saisie B :

A combien d'années remonte l'établissement du village :.....

Le Village est-il un village de colonie : (1=Oui ; $0=$ Non) : 


\section{IDENTITE DES REPONDANTS}

\begin{tabular}{|c|c|c|c|c|}
\hline \multirow[t]{2}{*}{$\mathbf{N}^{\circ}$} & \multirow[t]{2}{*}{ Catégorie } & \multicolumn{2}{|c|}{$\begin{array}{l}\text { Nombre pour chaque } \\
\text { catégorie }\end{array}$} & \multirow[t]{2}{*}{ TOTAL* } \\
\hline & & Homme & Femme & \\
\hline I.1 & $\begin{array}{l}\text { Autorités } \\
\text { gouvernementales/Représentants de } \\
\text { l'administration }\end{array}$ & | & 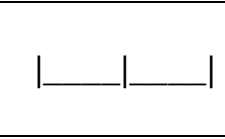 & L_ـ \\
\hline 1.2 & Chefs de village & 1 & 1 & 1 \\
\hline 1.3 & Délégués CVD & 1 & 1 & $1 \ldots$ \\
\hline 1.4 & Chefs de terre & 1 & | & 1 \\
\hline 1.5 & Chefs religieux (Imam, Pasteur, Prêtre....) & $1 \ldots$ & L_ــ & 1 \\
\hline 1.6 & $\begin{array}{l}\text { Responsables de } \\
\text { Groupements/Associations }\end{array}$ & 1 & 1 & $1 \ldots$ \\
\hline 1.7 & TOTAL* & L__ & L_ـ_ & 1 \\
\hline
\end{tabular}

* A compléter après l'interview avec le groupe

\section{COMPOSITION ACTUELLE DES COMMUNAUTES DU VILLAGE}

\begin{tabular}{|l|l|l|}
\hline $\mathbf{N}^{\circ}$ & Questions & Réponse \\
\hline II.1 & $\begin{array}{l}\text { Nombre approximatif d'autochtones revenus de la Côte } \\
\text { d'Ivoire à cause de la crise ivoirienne }\end{array}$ \\
\hline II.2 & Nombre approximatif d'immigrants venant d'ailleurs \\
\hline II.3 & $\begin{array}{l}\text { Nombre de groupes ethniques dans la communauté du } \\
\text { village }\end{array}$ \\
\hline II.4 & Nombre de clans dans le village & \\
\hline
\end{tabular}




\section{POPULATION DU VILLAGE}

NB : Pour cette partie, l'enquêteur devra se rendre à la préfecture ou à la mairie de la localité

\begin{tabular}{|c|c|c|c|}
\hline $\mathbf{N}^{\circ}$ & \multicolumn{2}{|l|}{ Questions } & Réponse \\
\hline III.1 & \multicolumn{2}{|c|}{$\begin{array}{l}\text { Existence des documents du recensement de } 2006 \\
\text { (1=Oui ; 0=Non) }\end{array}$} & L \\
\hline III.2 & \multicolumn{2}{|c|}{ Population totale en 2006} & $\mid$ \\
\hline III.3 & \multirow{2}{*}{$\begin{array}{c}\text { Population de plus de } 15 \\
\text { ans }\end{array}$} & Homme & 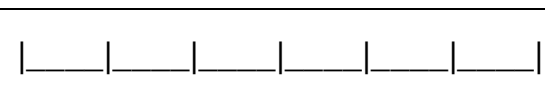 \\
\hline III.4 & & Femme & $\mid$ \\
\hline III.5 & \multirow{2}{*}{$\begin{array}{l}\text { Population de moins de } 15 \\
\text { ans }\end{array}$} & Homme & $\mid$ \\
\hline III.6 & & Femme & $\mid$ \\
\hline III.7 & \multicolumn{2}{|c|}{$\begin{array}{l}\text { Existence des documents du recensement de } 1996 \\
\text { (1=Oui ; 0=Non) }\end{array}$} & 1 \\
\hline III.8 & \multicolumn{2}{|c|}{ Population totale en 1996} & $\mid$ \\
\hline III.9 & \multirow{2}{*}{$\begin{array}{c}\text { Population de plus de } 15 \\
\text { ans }\end{array}$} & Homme & | \\
\hline III.10 & & Femme & $\mid$ \\
\hline III.11 & \multirow{2}{*}{$\begin{array}{c}\text { Population de moins de } 15 \\
\text { ans }\end{array}$} & Homme & $\mid$ \\
\hline III.12 & & Femme & | \\
\hline III.13 & \multicolumn{2}{|c|}{$\begin{array}{l}\text { Existence des documents du recensement de } 1985 \\
\text { (1=Oui ; 0=Non) }\end{array}$} & L \\
\hline III.14 & \multicolumn{2}{|c|}{ Population totale en 1985} & $\mid$ \\
\hline III.15 & \multirow{2}{*}{$\begin{array}{l}\text { Population de plus de } 15 \\
\text { ans }\end{array}$} & Homme & $\mid$ \\
\hline III.16 & & Femme & $\mid$ \\
\hline III.17 & \multirow{2}{*}{$\begin{array}{l}\text { Population de moins de } 15 \\
\text { ans }\end{array}$} & Homme & | \\
\hline III.18 & & Femme & $\mid$ \\
\hline
\end{tabular}




\section{IV.VISITE D'UN OFFICIEL DE LA VULGARISATION AGRICOLE}

\begin{tabular}{|l|l|l|}
\hline$N^{\circ}$ & Questions & Réponse \\
\hline IV.1 & $\begin{array}{c}\text { Quand a été la première visite d'un vulgarisateur à votre } \\
\text { communauté ? } \\
\text { (Inscrire l'année ou xxxx } \\
\text { IV.2 }\end{array}$ & $\begin{array}{l}\text { Quand est-ce que la vulgarisation de proximité (ancienne } \\
\text { formule) a cessé ? } \\
\text { jamais) }\end{array} \quad \begin{array}{c}\text { Quanscrire l'année ou xxxx si } \\
\text { comment-ce que la vulgarisation nouvelle formule a }\end{array}$ \\
\hline IV.3 & $\begin{array}{c}\text { Quand a été la dernière visite d'un vulgarisateur à votre } \\
\text { communauté ? (Inscrire l'année ou xxxx si jamais) }\end{array}$ \\
\hline IV.4 & $\begin{array}{c}\text { Combien de visites avez vous reçus au cours des 12 derniers } \\
\text { mois ? (Inscrire l'année ou xxxx si jamais) }\end{array}$ \\
\hline IV.5
\end{tabular}




\section{INFRASTRUCTURES CENTRALES : DISTANCES ET CHANGEMENTS}

\begin{tabular}{|c|c|c|c|}
\hline \multirow[t]{2}{*}{$\mathbf{N}^{\circ}$} & \multirow[t]{2}{*}{ Questions } & \multicolumn{2}{|l|}{ Réponse } \\
\hline & & Distance (en km) & $\begin{array}{l}\text { Année } \\
\text { d'établissement }\end{array}$ \\
\hline V.1 & \multicolumn{3}{|c|}{$\begin{array}{l}\text { Distance entre le village et l'administration centrale (pour les registres des } \\
\text { naissances) }\end{array}$} \\
\hline V.1.1 & La situation actuelle & 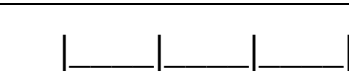 & 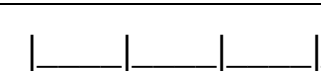 \\
\hline V.1.2 & La situation précédente & 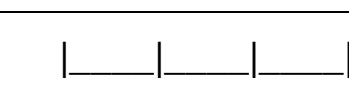 & L_L \\
\hline V.1.3 & La situation antécédente & & \\
\hline V.2 & \multicolumn{3}{|c|}{ Distance entre le village et la route praticable par car ou camion toute l'année } \\
\hline V.2.1 & La situation actuelle & & \\
\hline V.2.2 & La situation précédente & & \\
\hline V.2.3 & La situation antécédente & & \\
\hline V.3 & \multicolumn{3}{|c|}{$\begin{array}{l}\text { Distance entre le village et la route praticable par car ou camion seulement une } \\
\text { partie de l'année }\end{array}$} \\
\hline V.3.1 & La situation actuelle & & \\
\hline V.3.2 & La situation précédente & & \\
\hline V.3.3 & La situation antécédente & & \\
\hline V.4 & \multicolumn{3}{|c|}{ Distance entre le village et l'arrêt d'autocar/taxi brousse rural } \\
\hline V.4.1 & La situation actuelle & & \\
\hline V.4.2 & La situation précédente & & \\
\hline V.4.3 & La situation antécédente & & \\
\hline V.5 & \multicolumn{3}{|c|}{ Distance entre le village et le bureau des caisses populaires } \\
\hline V.5.1 & La situation actuelle & & \\
\hline V.5.2 & La situation précédente & 1_L & L_ L \\
\hline V.5.3 & La situation antécédente & l_ & L_L \\
\hline
\end{tabular}




\begin{tabular}{|c|c|c|c|}
\hline V.6 & \multicolumn{3}{|c|}{ Distance entre le village et la localité avec distribution d'électricité } \\
\hline V.6.1 & La situation actuelle & L__ L & L L L L \\
\hline V.6.2 & La situation précédente & $\mid$ & 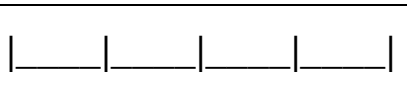 \\
\hline V.6.3 & La situation antécédente & $\mid$ & L 1 \\
\hline V.7 & \multicolumn{3}{|c|}{ Distance entre le village et la localité avec le téléphone fixe } \\
\hline V.7.1 & La situation actuelle & $\mathrm{L}$ & L__ \\
\hline V.7.2 & La situation précédente & 1 & 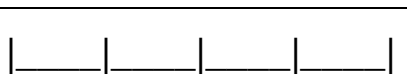 \\
\hline V.7.3 & La situation antécédente & L__ & _ \\
\hline V.8 & \multicolumn{3}{|c|}{ Distance entre le village et la localité avec la téléphonie mobile } \\
\hline V.8.1 & La situation actuelle & $\mid$ & L_ـ \\
\hline V.8.2 & La situation précédente & L_ & L__ \\
\hline V.8.3 & La situation antécédente & 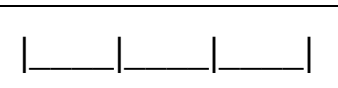 & | \\
\hline
\end{tabular}


VI.MARCHES VILLAGEOIS

\begin{tabular}{|c|c|c|c|c|}
\hline $\mathbf{N}^{\circ}$ & Questions & \multicolumn{3}{|l|}{ Réponse } \\
\hline \multirow[t]{2}{*}{ VI.1 } & \multicolumn{4}{|c|}{ FREQUENCE DU MARCHE GENERAL } \\
\hline & & $\begin{array}{l}\text { Distance (en } \\
\text { km) }\end{array}$ & $\begin{array}{l}\text { Fréquence } \\
1=\text { chaque jour } \\
2=\text { tous les } 3 \text { jours } \\
3=\text { tous les } 4 \text { jours } \\
4=\text { chaque semaine } \\
5=\text { occasionnel }\end{array}$ & $\begin{array}{l}\text { Année } \\
\text { d'établissement }\end{array}$ \\
\hline VI.1.1 & $\begin{array}{l}\text { La situation } \\
\text { actuelle }\end{array}$ & | & L & 1 \\
\hline VI.1.2 & $\begin{array}{l}\text { La situation } \\
\text { précédente }\end{array}$ & | & L & l_ l \\
\hline VI.1.3 & $\begin{array}{l}\text { La situation } \\
\text { antécédente }\end{array}$ & | & 1 & $\mid$ \\
\hline \multirow[t]{2}{*}{ VI.2 } & \multicolumn{4}{|c|}{ TYPE DE SOURCE POUR ACCES A L’EAU DANS LE MARCHE GENERAL } \\
\hline & & & $\begin{array}{l}\text { Type de source } \\
\text { d'eau } \\
1=\text { robinet } \\
2=\text { borne fontaine } \\
3=\text { forage } \\
4=\text { puits } \\
5=\text { aucune } \\
\end{array}$ & $\begin{array}{l}\text { Année } \\
\text { d'établissement }\end{array}$ \\
\hline VI.2.1 & \multicolumn{2}{|c|}{ La situation actuelle } & $\mid$ & 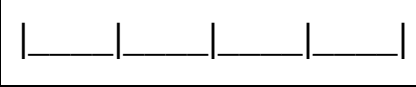 \\
\hline VI.2.2 & \multicolumn{2}{|c|}{ La situation précédente } & $\mid$ & 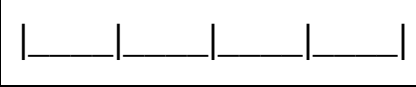 \\
\hline VI.2.3 & \multicolumn{2}{|c|}{ La situation antécédente } & $\mid$ & 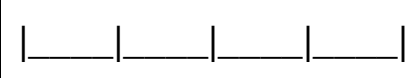 \\
\hline \multirow[t]{2}{*}{ VI.3 } & \multicolumn{4}{|c|}{ HANGARS DANS LE MARCHE GENERAL } \\
\hline & & & $\begin{array}{l}\text { Type de hangar } \\
1=\text { individuel } \\
2=\text { collectif } \\
3=\text { aucun }\end{array}$ & $\begin{array}{l}\text { Année } \\
\text { d'établissement }\end{array}$ \\
\hline VI.3.1 & \multicolumn{2}{|c|}{ La situation actuelle } & $\mid$ & $\mid$ \\
\hline VI.3.2 & \multicolumn{2}{|c|}{ La situation précédente } & $\mid$ & | \\
\hline VI.3.3 & \multicolumn{2}{|c|}{ La situation antécédente } & $\mid$ & | \\
\hline
\end{tabular}




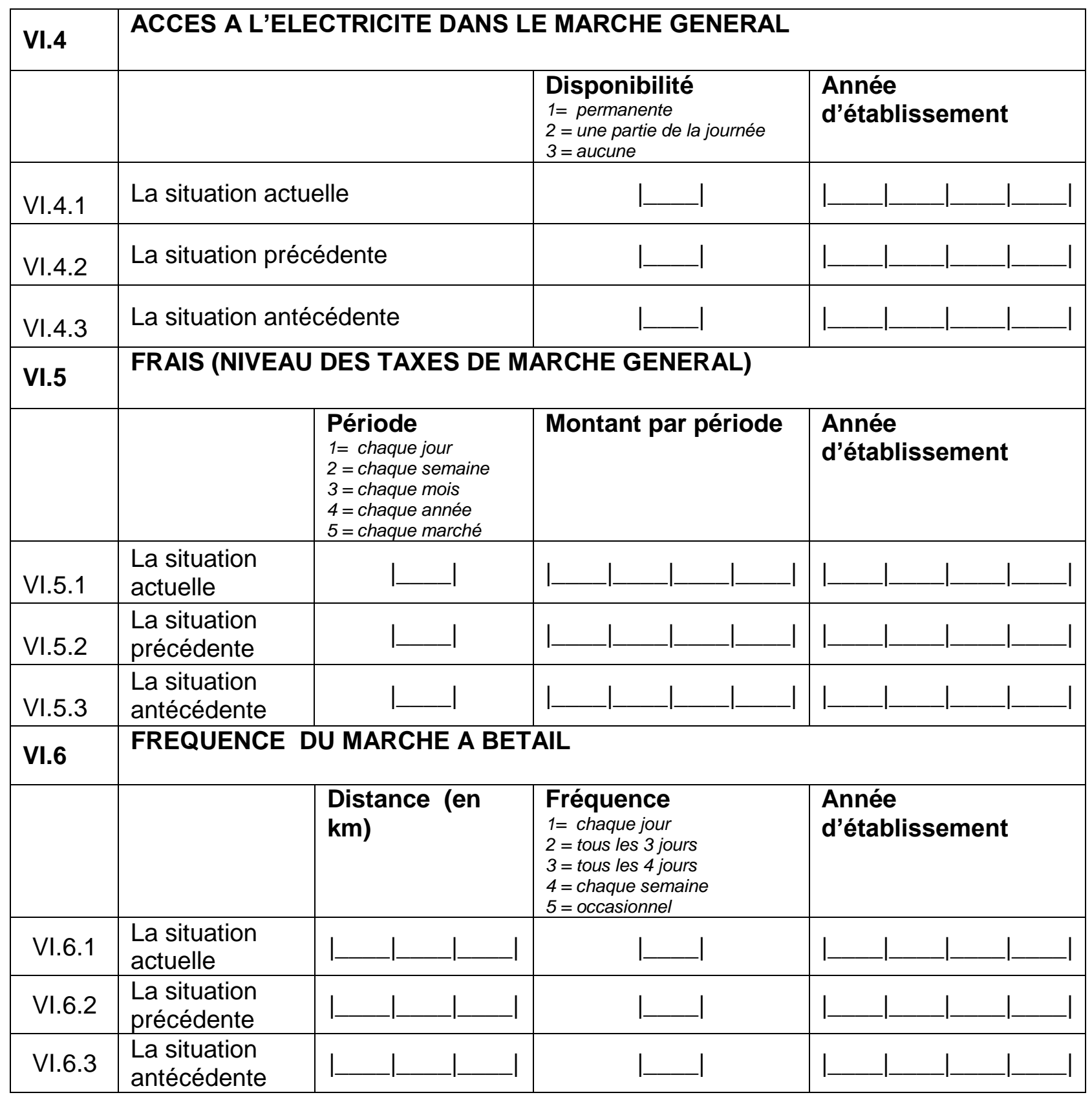




\begin{tabular}{|c|c|c|c|c|}
\hline VI.7 & \multicolumn{4}{|c|}{ TYPE DE SOURCE POUR ACCES A L'EAU DANS LE MARCHE A BETAIL } \\
\hline & & & $\begin{array}{l}\text { Type de source } \\
\text { d'eau } \\
1=\text { robinet } \\
2=\text { borne fontaine } \\
3=\text { forage } \\
4=\text { puits } \\
5=\text { aucune } \\
\end{array}$ & $\begin{array}{l}\text { Année } \\
\text { d'établissement }\end{array}$ \\
\hline VI.7.1 & \multicolumn{2}{|c|}{ La situation actuelle } & $\mid$ & L_ \\
\hline VI.7.2 & \multicolumn{2}{|c|}{ La situation précédente } & $\mid$ & 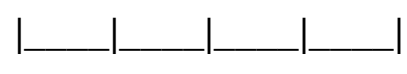 \\
\hline VI.7.3 & \multicolumn{2}{|c|}{ La situation antécédente } & $\mid$ & 1 \\
\hline \multirow[t]{2}{*}{ VI.8 } & \multicolumn{4}{|c|}{ HANGARS DANS LE MARCHE A BETAIL } \\
\hline & & $\begin{array}{l}\text { Type de hangar } \\
1=\text { individuel } \\
2=\text { collectif } \\
3=\text { aucun }\end{array}$ & $\begin{array}{l}\text { Année } \\
\text { d'établissement }\end{array}$ \\
\hline VI.8.1 & \multicolumn{2}{|c|}{ La situation actuelle } & $\mid$ & $\mid$ \\
\hline VI.8.2 & \multicolumn{2}{|c|}{ La situation précédente } & $\mid$ & $\mid$ \\
\hline VI.8.3 & \multicolumn{2}{|c|}{ La situation antécédente } & $\mid$ & $\mid$ \\
\hline VI.9 & \multicolumn{4}{|c|}{ ACCES A L'ELECTRICITE DANS LE MARCHE A BETAIL } \\
\hline & \multicolumn{2}{|c|}{ 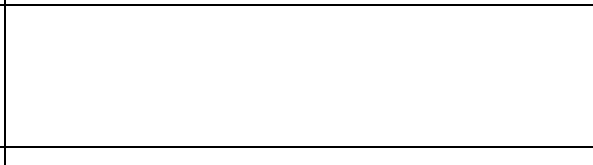 } & $\begin{array}{l}\text { Disponibilité } \\
1=\text { permanente } \\
2=\text { une partie de la journée } \\
3=\text { aucune }\end{array}$ & $\begin{array}{l}\text { Année } \\
\text { d'établissement }\end{array}$ \\
\hline VI.9.1 & \multicolumn{2}{|c|}{ La situation actuelle } & L & 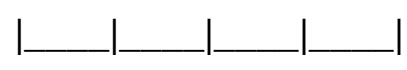 \\
\hline VI.9.2 & \multicolumn{2}{|c|}{ La situation précédente } & L & 1 \\
\hline VI.9.3 & \multicolumn{2}{|c|}{ La situation antécédente } & $\mathrm{L}$ & 1 \\
\hline \multirow[t]{2}{*}{ VI.10 } & \multicolumn{4}{|c|}{ FRAIS (NIVEAU DES TAXES DE MARCHE) A BETAIL } \\
\hline & & $\begin{array}{l}\text { Période } \\
1=\text { chaque jour } \\
2=\text { chaque semaine } \\
3=\text { chaque mois } \\
4=\text { chaque année } \\
5=\text { chaque marché }\end{array}$ & Montant par période & $\begin{array}{l}\text { Année } \\
\text { d'établissement }\end{array}$ \\
\hline VI.10.1 & $\begin{array}{l}\text { La situation } \\
\text { actuelle }\end{array}$ & 1 & | & | \\
\hline VI.10.2 & $\begin{array}{l}\text { La situation } \\
\text { précédente }\end{array}$ & 1 & 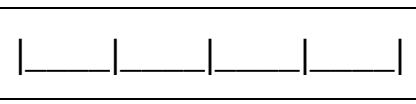 & | \\
\hline VI.10.3 & $\begin{array}{l}\text { La situation } \\
\text { antécédente }\end{array}$ & 1 & 1 & 1 \\
\hline
\end{tabular}


VII.INFRASTRUCTURE DU VILLAGE

\begin{tabular}{|c|c|c|c|c|}
\hline \multirow[t]{2}{*}{$\mathbf{N}^{\circ}$} & \multirow[t]{2}{*}{ Questions } & \multicolumn{3}{|l|}{ Réponse } \\
\hline & & Distance & Nombre & $\begin{array}{l}\text { Année } \\
\text { d'établissement }\end{array}$ \\
\hline $\begin{array}{l}\text { VII.1 } \\
\end{array}$ & \multicolumn{4}{|c|}{$\begin{array}{l}\text { Distance entre le village et les boutiques pour achat des provisions divers (sel, } \\
\text { thé, sucre, etc.) }\end{array}$} \\
\hline VII.1.1 & La situation actuelle & 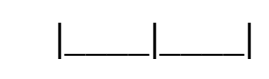 & | & 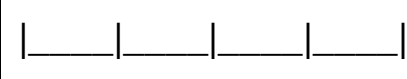 \\
\hline VII.1.2 & $\begin{array}{l}\text { La situation } \\
\text { précédente }\end{array}$ & 1 & | & 1 \\
\hline VII.1.3 & $\begin{array}{l}\text { La situation } \\
\text { antécédente }\end{array}$ & 1 & $1 \ldots$ & 1 \\
\hline VII.2 & \multicolumn{4}{|c|}{ Distance entre le village et les puits collectifs pour l'eau potable } \\
\hline VII.2.1 & La situation actuelle & 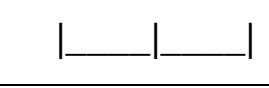 & 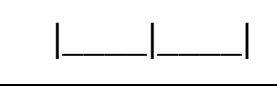 & 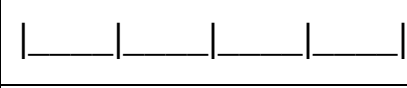 \\
\hline VII.2.2 & $\begin{array}{l}\text { La situation } \\
\text { précédente }\end{array}$ & | & 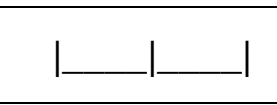 & | \\
\hline VII.2.3 & $\begin{array}{l}\text { La situation } \\
\text { antécédente }\end{array}$ & $\mid$ & $\mid$ & 1 \\
\hline VII.3 & \multicolumn{4}{|c|}{ Distance entre le village et le puits à grand diamètre } \\
\hline VII.3.1 & La situation actuelle & | & L__ l & 1 \\
\hline VII.3.2 & $\begin{array}{l}\text { La situation } \\
\text { précédente }\end{array}$ & 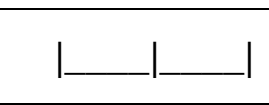 & | & L__ \\
\hline VII.3.3 & $\begin{array}{l}\text { La situation } \\
\text { antécédente }\end{array}$ & $\mid$ & 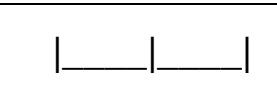 & 1 \\
\hline VII.4 & \multicolumn{4}{|c|}{ Distance entre le village et le forage collectif pour l'eau potable } \\
\hline VII.4.1 & La situation actuelle & L___ & | & 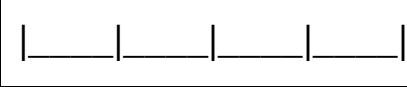 \\
\hline VII.4.2 & $\begin{array}{l}\text { La situation } \\
\text { précédente }\end{array}$ & 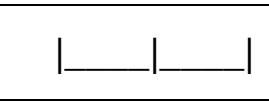 & | & $\mid$ \\
\hline VII.4.3 & $\begin{array}{l}\text { La situation } \\
\text { antécédente }\end{array}$ & 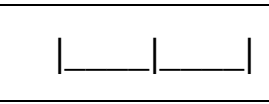 & | & $\mid$ \\
\hline
\end{tabular}




\begin{tabular}{|c|c|c|c|c|}
\hline VII.5 & \multicolumn{4}{|c|}{ Distance entre le village et le Barrage collectif } \\
\hline VII.5.1 & La situation actuelle & L__ & | & | \\
\hline VII.5.2 & $\begin{array}{l}\text { La situation } \\
\text { précédente }\end{array}$ & 1 & L_ـ & $\mid$ \\
\hline VII.5.3 & $\begin{array}{l}\text { La situation } \\
\text { antécédente }\end{array}$ & L_ـ & | & $\mid$ \\
\hline VII.6 & \multicolumn{4}{|c|}{ Pont routier construit par le village } \\
\hline VII.6.1 & La situation actuelle & & 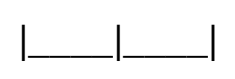 & | \\
\hline VII.6.2 & $\begin{array}{l}\text { La situation } \\
\text { précédente }\end{array}$ & & | & $1+1$ \\
\hline VII.6.3 & $\begin{array}{l}\text { La situation } \\
\text { antécédente }\end{array}$ & & L__ & $\mid$ \\
\hline VII.7 & \multicolumn{4}{|c|}{ Passage piétonnier construit par le village } \\
\hline VII.7.1 & La situation actuelle & & | & | \\
\hline VII.7.2 & $\begin{array}{l}\text { La situation } \\
\text { précédente }\end{array}$ & & L__ & L__ \\
\hline VII.7.3 & $\begin{array}{l}\text { La situation } \\
\text { antécédente }\end{array}$ & & | & 1 \\
\hline VII.8 & \multicolumn{4}{|c|}{$\begin{array}{l}\text { Magasin (utilisable) de coopérative agricole, d'ONG ou de Groupement } \\
\text { Villageois }\end{array}$} \\
\hline VII.8.1 & La situation actuelle & & L__ـ & 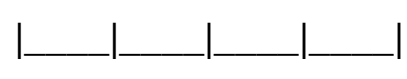 \\
\hline VII.8.2 & $\begin{array}{l}\text { La situation } \\
\text { précédente }\end{array}$ & & 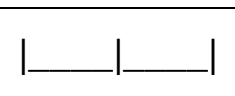 & 1 \\
\hline VII.8.3 & $\begin{array}{l}\text { La situation } \\
\text { antécédente }\end{array}$ & & 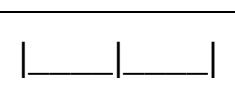 & $1+1$ \\
\hline
\end{tabular}




\section{DROITS FONCIERS SUR LES TERRES DE CULTURE}

\begin{tabular}{|c|c|c|c|}
\hline $\mathbf{N}^{\circ}$ & Questions & \multicolumn{2}{|l|}{ Réponse } \\
\hline VIII.1 & \multicolumn{3}{|c|}{$\begin{array}{l}\text { Type de droit appliquée pour les terres de culture } \\
\text { (si la réponse est non, mettre des croix à année de début d'application) }\end{array}$} \\
\hline & & $\begin{array}{l}\text { Type de droit } \\
\text { appliquée } \\
\text { (1=Oui ; } 0=\text { Non })\end{array}$ & $\begin{array}{l}\text { Année de début } \\
\text { d'application }\end{array}$ \\
\hline VIII.1.1 & Propriété individuelle & l & \\
\hline VIII.1.2 & Propriété collective-familiale & 1 & \\
\hline VIII.1.3 & Propriété collective-communautaire & L & \\
\hline VIII.2 & \multicolumn{3}{|c|}{$\begin{array}{l}\text { Location, vente et prêts de terres de culture } \\
\text { (si la réponse est non, mettre des croix à année de début d'application) }\end{array}$} \\
\hline & & $\begin{array}{l}\text { Possibilité de } \\
\text { transaction } \\
(1=\text { Oui ; 0=Non) }\end{array}$ & $\begin{array}{l}\text { Année de début } \\
\text { d'application }\end{array}$ \\
\hline VIII.2.1 & Est-ce que la terre peut-être louée ? & & \\
\hline VIII.2.2 & Est-ce que la terre peut-être vendue ? & 1 & \\
\hline VIII.2.3 & Est-ce que la terre peut-être prêtée ? & 1 & \\
\hline VIII.3 & \multicolumn{3}{|c|}{$\begin{array}{l}\text { Est-ce qu'il y a des terres de culture qui ont étés louées ? } \\
\text { (si non à la question VIII.2.1, mettre des croix dans les bacs et passer à la question suivante) }\end{array}$} \\
\hline & & $\begin{array}{l}\text { Location de terre } \\
(1=\text { Oui ; } 0=\text { Non) }\end{array}$ & $\begin{array}{l}\text { Année de début } \\
\text { d'application }\end{array}$ \\
\hline VIII.3.1 & Louées à une personne autochtone & r & \\
\hline VIII.3.2 & Louées à une personne étrangère & 1 & \\
\hline VIII.4 & \multicolumn{3}{|c|}{$\begin{array}{l}\text { A qui devrait-on demander permission pour louer ses terres? } \\
\text { (cette question devra être toujours posée quelque soit la réponse de la question précédente) }\end{array}$} \\
\hline & & $\begin{array}{l}\text { Personnes ressources } \\
1=\text { chef de famille } \\
2=\text { chef de terre } \\
3=\text { conseil élu par la } \\
\text { communauté } \\
4=\text { conseil élu par le } \\
\text { gouvernement } \\
5=\text { aucune permission }\end{array}$ & $\begin{array}{l}\text { Année de début } \\
\text { d'application }\end{array}$ \\
\hline VIII.4.1 & La situation actuelle & $\mid$ & \\
\hline VIII.4.2 & La situation précédente & $\mid$ & 1 \\
\hline VIII.4.3 & La situation antécédente & $\mid$ & 1 \\
\hline VIII.5 & \multicolumn{3}{|c|}{$\begin{array}{l}\text { Est-ce qu'il y a des terres de culture qui ont étés vendues ? } \\
\text { (si non à la question VIII.2.2, mettre des croix dans les bacs et passer à la question suivante) }\end{array}$} \\
\hline
\end{tabular}




\begin{tabular}{|c|c|c|c|}
\hline & & $\begin{array}{l}\text { Ventes de terre } \\
(1=\text { Oui ; } 0=\text { Non })\end{array}$ & $\begin{array}{l}\text { Année de début } \\
\text { d'application }\end{array}$ \\
\hline VIII.5.1 & $\begin{array}{l}\text { Vendues à une personne } \\
\text { autochtone? }\end{array}$ & 1 & $1 \ldots$ \\
\hline VIII.5.2 & $\begin{array}{ll}\text { Vendues } & \text { à une personne } \\
\text { étrangère? }\end{array}$ & | & 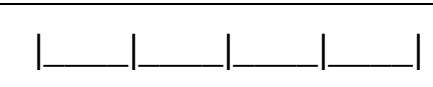 \\
\hline \multirow[t]{2}{*}{ VIII.6 } & \multicolumn{3}{|c|}{$\begin{array}{l}\text { A qui devrait-on demander permission pour vendre ses terres? } \\
\text { (cette question devra être toujours posée quelque soit la réponse de la question précédente) }\end{array}$} \\
\hline & & $\begin{array}{l}\text { Personnes ressources } \\
1=\text { chef de famille } \\
2=\text { chef de terre } \\
3=\text { conseil élu par la } \\
\text { communauté } \\
4=\text { conseil élu par le } \\
\text { gouvernement } \\
5=\text { aucune permission }\end{array}$ & $\begin{array}{l}\text { Année de début } \\
\text { d'application }\end{array}$ \\
\hline VIII.6.1 & La situation actuelle & $\mid$ & 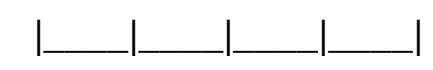 \\
\hline VIII.6.2 & La situation précédente & $\mid$ & | \\
\hline VIII.6.3 & La situation antécédente & $\mid$ & L_ \\
\hline \multirow[t]{2}{*}{ VIII.7 } & \multicolumn{3}{|c|}{$\begin{array}{l}\text { Est-ce qu'il y a des terres de culture qui ont étés prêtées ? } \\
\text { (si non à la question VIII.2.3, mettre des croix dans les bacs et passer à la question suivante) }\end{array}$} \\
\hline & & $\begin{array}{l}\text { Prêts de terre } \\
(1=\text { Oui } ; 0=\text { Non })\end{array}$ & $\begin{array}{l}\text { Année de début } \\
\text { d'application }\end{array}$ \\
\hline VIII.7.1 & Prêtées à une personne autochtone & 1 & $\mid$ \\
\hline VIII.7.2 & Prêtées à une personne étrangère & L & L_ا__L \\
\hline \multirow[t]{2}{*}{ VIII.8 } & \multicolumn{3}{|c|}{$\begin{array}{l}\text { A qui devrait-on demander permission pour prêter ses terres? } \\
\text { (cette question devra être toujours posée quelque soit la réponse de la question précédente) }\end{array}$} \\
\hline & & $\begin{array}{l}\text { Personnes ressources } \\
1=\text { chef de famille } \\
2=\text { chef de terre } \\
3=\text { conseil élu par la } \\
\text { communauté } \\
4=\text { conseil élu par le } \\
\text { gouvernement } \\
5=\text { aucune permission }\end{array}$ & $\begin{array}{l}\text { Année de début } \\
\text { d'application }\end{array}$ \\
\hline VIII.8.1 & La situation actuelle & 1 & $1 \ldots$ \\
\hline VIII.8.2 & La situation précédente & $\mid$ & | \\
\hline VIII.8.3 & La situation antécédente & $\mid$ & | \\
\hline
\end{tabular}




\begin{tabular}{|c|c|c|c|}
\hline \multirow[t]{2}{*}{ VIII.9 } & \multicolumn{3}{|c|}{$\begin{array}{l}\text { A qui devrait-on s'adresser pour résoudre un conflit foncier pour l'usage des terres de } \\
\text { culture? }\end{array}$} \\
\hline & & $\begin{array}{l}\text { Personnes ressources } \\
1=\text { chef de terre } \\
2=\text { chef ou conseil élu par la } \\
\text { communauté } \\
3=\text { chef ou conseil nommé par le } \\
\text { gouvernement } \\
4=\text { autre type d'autorité } \\
5=\text { aucune autorité }\end{array}$ & $\begin{array}{l}\text { Année de début } \\
\text { d'application }\end{array}$ \\
\hline VIII.9.1 & La situation actuelle & $\mid$ & 1 \\
\hline VIII.9.2 & La situation précédente & $\mid$ & 1 \\
\hline VIII.9.3 & La situation antécédente & $\mid$ & 1 \\
\hline \multirow[t]{2}{*}{ VIII.10 } & \multicolumn{3}{|c|}{$\begin{array}{l}\text { Quelles sont les modes de propriété des terres de pâturages dans cette communauté } \\
\text { (s'il n'existe pas de terre de pâturage, mettre des croix dans les bacs et passer à la question suivante) }\end{array}$} \\
\hline & & $\begin{array}{l}\text { Personnes ressources } \\
1=\text { propriété individuelle } \\
2=\text { propriéte collective-familiale } \\
3=\text { propriététe collective-ligagère } \\
4=\text { propriéte collective- } \\
\text { communautaire } \\
5=\text { autre }\end{array}$ & $\begin{array}{l}\text { Année de début } \\
\text { d'application }\end{array}$ \\
\hline VIII.10.1 & La situation actuelle & $\mid$ & L_ \\
\hline VIII.10.2 & La situation précédente & $\mid$ & | 1 \\
\hline \multirow{3}{*}{$\begin{array}{l}\text { VIII.10.3 } \\
\text { VIII.11 }\end{array}$} & La situation antécédente & $\mid$ & 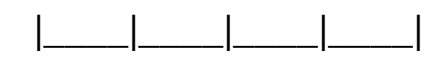 \\
\hline & \multicolumn{3}{|c|}{$\begin{array}{l}\text { Combien de pistes à bétail y a-t-il dans le village } \\
\text { (s'il n'existe pas de pistes à bétail, mettre des croix dans les bacs et passer à la question suivante) }\end{array}$} \\
\hline & & Nombre & $\begin{array}{l}\text { Année de début } \\
\text { d'application }\end{array}$ \\
\hline VIII.11.1 & La situation actuelle & L & | \\
\hline VIII.11.2 & La situation précédente & L ا & L 1 \\
\hline VIII.11.3 & La situation antécédente & L & 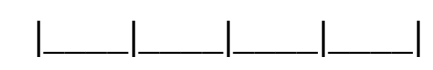 \\
\hline
\end{tabular}




\section{IX.DROITS FONCIERS POUR LES TERRES DE PATURAGE}

\begin{tabular}{|c|c|c|c|}
\hline $\mathbf{N}^{\circ}$ & Questions & \multicolumn{2}{|l|}{ Réponse } \\
\hline IX.1 & \multicolumn{3}{|c|}{$\begin{array}{l}\text { Existe-t-il des terres réservées pour le pâturage ? } \\
\text { (si la réponse est non pour une situation donnée, mettre des croix à année } \\
\text { d'établissement) }\end{array}$} \\
\hline & & $\begin{array}{l}\text { Existence de } \\
\text { pâturage } \\
(1=\text { Oui ; } 0=\text { Non) }\end{array}$ & $\begin{array}{l}\text { Année } \\
\text { d'établissement }\end{array}$ \\
\hline IX.1.1 & La situation actuelle & L & l 1 \\
\hline IX.1.2 & $\begin{array}{l}\text { La situation } \\
\text { précédente }\end{array}$ & 1 & | \\
\hline IX.1.3 & $\begin{array}{l}\text { La situation } \\
\text { antécédente }\end{array}$ & L & | 1 \\
\hline IX.2 & \multicolumn{3}{|c|}{$\begin{array}{l}\text { Quelles sont les voies d'accès aux pâturages ? } \\
\text { (si la réponse est } 2 \text { (tout autre piste), mettre des croix à année d'établissement) }\end{array}$} \\
\hline IX.2.1 & & $\begin{array}{l}\text { Voies d'accès } \\
1=\text { pistes à bétail } \\
2=\text { tout autre piste }\end{array}$ & $\begin{array}{l}\text { Année } \\
\text { d'établissement }\end{array}$ \\
\hline IX.2.2 & La situation actuelle & L & | \\
\hline \multirow[t]{2}{*}{ IX.2.3 } & $\begin{array}{l}\text { La situation } \\
\text { précédente }\end{array}$ & 1 & | 1 \\
\hline & $\begin{array}{l}\text { La situation } \\
\text { antécédente }\end{array}$ & L & | \\
\hline
\end{tabular}




\begin{tabular}{|c|c|c|c|}
\hline \multirow[t]{2}{*}{ IX.3 } & \multicolumn{3}{|c|}{$\begin{array}{l}\text { Quels moyens existent pour limiter l'accès aux terres de } \\
\text { pâturages? } \\
\text { (si la réponse est non pour une situation donnée à la question IX.1, mettre des croix dans } \\
\text { la situation correspondante à cette question ci) }\end{array}$} \\
\hline & & $\begin{array}{l}\text { Moyens de } \\
\text { paiement } \\
1=\text { paiement d'une taxe par } \\
\text { animal } \\
2=\text { paiement d'un autre type } \\
\text { de taxe } \\
3=\text { contrôle du nombre } \\
\text { d'animaux } \\
4=\text { accès illimité pour } \\
\text { autochtones } \\
5=\text { accès illimité pour } \\
\text { résidents } \\
6=\text { aucune restriction }\end{array}$ & $\begin{array}{l}\text { Année } \\
\text { d'établissement }\end{array}$ \\
\hline IX.3.1 & La situation actuelle & $|\ldots|-\mid$ & _ \\
\hline IX.3.2 & $\begin{array}{l}\text { La situation } \\
\text { précédente }\end{array}$ & $\mid$ & I__ \\
\hline IX.3.3 & $\begin{array}{l}\text { La situation } \\
\text { antécédente }\end{array}$ & $\mid$ & l_ $1 \ldots 1 \ldots$ \\
\hline \multirow[t]{2}{*}{ IX.4 } & \multicolumn{3}{|c|}{ Qui est responsable pour gérer l'accès aux terres de pâturages ? } \\
\hline & & $\begin{array}{l}\text { Personnes } \\
\text { ressources } \\
1=\text { chef de terre } \\
2=\text { chef ou conseil élu par la } \\
\text { communauté } \\
3=\text { chef ou conseil nommé } \\
\text { par le gouvernement } \\
4=\text { autre type d'autorité } \\
5=\text { aucune autorité }\end{array}$ & $\begin{array}{l}\text { Année } \\
\text { d'établissement }\end{array}$ \\
\hline IX.4.1 & La situation actuelle & $\mid$ & 1 \\
\hline IX.4.2 & $\begin{array}{l}\text { La situation } \\
\text { précédente }\end{array}$ & $\mid$ & L_L \\
\hline IX.4.3 & $\begin{array}{l}\text { La situation } \\
\text { antécédente }\end{array}$ & $\mid$ & 1 \\
\hline
\end{tabular}


X.DROITS D'UTILISATION DES FORETS (POUR LE BOIS, LES FRUITS, LA CHASSE ETC.)

\begin{tabular}{|c|c|c|c|}
\hline $\mathbf{N}^{\circ}$ & Questions & \multicolumn{2}{|l|}{ Réponse } \\
\hline $\mathbf{X . 1}$ & \multicolumn{3}{|c|}{$\begin{array}{l}\text { Existe-t-il des forêts dans votre communauté ? } \\
\text { (si la réponse est non pour une situation donnée, mettre des croix à année } \\
\text { d'établissement) }\end{array}$} \\
\hline & & $\begin{array}{l}\text { Existence de forêts } \\
(1=\text { Oui ; } 0=\text { Non })\end{array}$ & $\begin{array}{l}\text { Année } \\
\text { d'établissement }\end{array}$ \\
\hline$X .1 .1$ & La situation actuelle & - & L__ \\
\hline$X .1 .2$ & $\begin{array}{l}\text { La situation } \\
\text { précédente }\end{array}$ & $\mathrm{l}$ & 1 \\
\hline$X .1 .3$ & $\begin{array}{l}\text { La situation } \\
\text { antécédente }\end{array}$ & 1 & 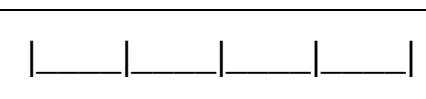 \\
\hline $\mathbf{X . 2}$ & \multicolumn{3}{|c|}{$\begin{array}{l}\text { Est-ce qu'il existe des moyens pour limiter l'accès aux forets ? } \\
\text { (si la réponse est non pour une situation donnée à la question X.1, mettre des croix dans } \\
\text { la situation correspondante à cette question ci) }\end{array}$} \\
\hline & & $\begin{array}{l}\text { Moyens de } \\
\text { paiement } \\
1=\text { paiement d'une taxe par } \\
\text { unité de bois } \\
2=\text { paiement d'une taxe par } \\
\text { autre moyen } \\
3=\text { contrôle direct des } \\
\text { entrées et sorties } \\
4=\text { accès illimité pour } \\
\text { autochtones } \\
5=\text { accès illimité pour } \\
\text { résidents } \\
6=\text { aucune restriction }\end{array}$ & $\begin{array}{l}\text { Année } \\
\text { d'établissement }\end{array}$ \\
\hline$X .2 .1$ & La situation actuelle & $\mid$ & 1 \\
\hline X.2.2 & $\begin{array}{l}\text { La situation } \\
\text { précédente }\end{array}$ & $\mid$ & \\
\hline$X .2 .3$ & $\begin{array}{l}\text { La situation } \\
\text { antécédente }\end{array}$ & $\mid$ & l____ L \\
\hline \multirow[t]{2}{*}{$\mathrm{X} .3$} & \multicolumn{3}{|c|}{ Qui est responsable de la gestion de l'accès aux forets ? } \\
\hline & & $\begin{array}{l}\text { Personnes } \\
\text { ressources } \\
1=\text { chef de terre } \\
2=\text { chef ou conseil élu par la } \\
\text { communauté } \\
3=\text { chef ou conseil nommé } \\
\text { par le gouvernement } \\
4=\text { autre type d'autorité } \\
5=\text { aucune autorité }\end{array}$ & $\begin{array}{l}\text { Année } \\
\text { d'établissement }\end{array}$ \\
\hline X.3.1 & La situation actuelle & $\mid$ & 1 \\
\hline X.3.2 & $\begin{array}{l}\text { La situation } \\
\text { précédente }\end{array}$ & $\mid$ & 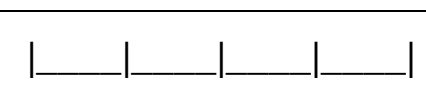 \\
\hline X.3.3 & $\begin{array}{l}\text { La situation } \\
\text { antécédente }\end{array}$ & $\mid$ & 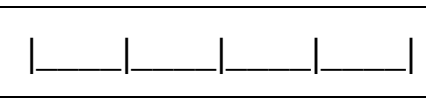 \\
\hline
\end{tabular}




\section{XI.INFRASTRUCTURE D'EDUCATION ET DE SANTE}

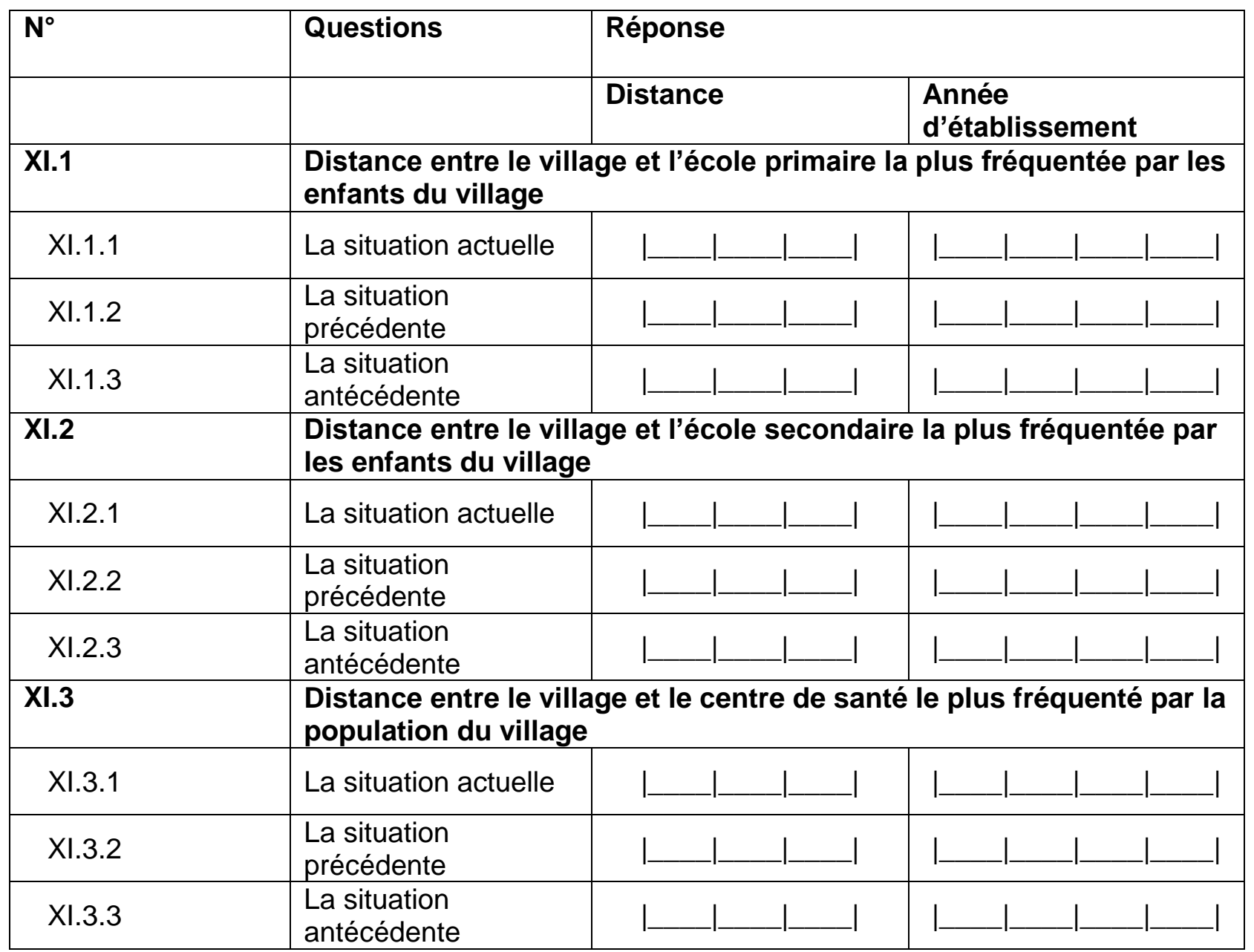




\section{XII.INFRASTRUCTURE RELIGIEUSES}

\begin{tabular}{|c|c|c|c|}
\hline $\mathbf{N}^{\circ}$ & Questions & & onse \\
\hline & & Distance & $\begin{array}{l}\text { Année } \\
\text { d'établissement }\end{array}$ \\
\hline XII.1 & $\begin{array}{l}\text { Distance entre le vi } \\
\text { population du villag }\end{array}$ & ge et l'église la plus & quentée par la \\
\hline XII.1.1 & La situation actuelle & 1 & 1 \\
\hline XII.1.2 & $\begin{array}{l}\text { La situation } \\
\text { précédente }\end{array}$ & L & L_ \\
\hline XII.1.3 & $\begin{array}{l}\text { La situation } \\
\text { antécédente }\end{array}$ & 1 & L \\
\hline XII.2 & $\begin{array}{l}\text { Distance entre le vi } \\
\text { population du villag }\end{array}$ & ge et la mosquée la & fréquentée par I \\
\hline XII.2.1 & La situation actuelle & 1 & | \\
\hline XII.2.2 & $\begin{array}{l}\text { La situation } \\
\text { précédente }\end{array}$ & & \\
\hline XII.2.3 & $\begin{array}{l}\text { La situation } \\
\text { antécédente }\end{array}$ & & \\
\hline XII.3 & $\begin{array}{l}\text { Distance entre le vi } \\
\text { population du villag }\end{array}$ & ge et le temple le plu & équenté par la \\
\hline XII.3.1 & La situation actuelle & 1 & 1 \\
\hline XII.3.2 & $\begin{array}{l}\text { La situation } \\
\text { précédente }\end{array}$ & 1 & 1 \\
\hline XII.3.3 & $\begin{array}{l}\text { La situation } \\
\text { antécédente }\end{array}$ & & \\
\hline
\end{tabular}

